\title{
Sub-surface geology and velocity structure of the Krafla high temperature geothermal field, Iceland: Integrated ditch cuttings, wireline and zero offset vertical seismic profile analysis
}

John M. Millett ${ }^{1,2}$, Sverre Planke ${ }^{1,3}$, Felix Kästner ${ }^{4,5}$, Anett Blischke ${ }^{6}$, Gylfi Páll Hersir ${ }^{5}$, Sæunn Halldórsdóttir 5 , Ólafur G. Flóvenz ${ }^{5}$, Sigurveig Árnadóttir ${ }^{6}$, Helga M. Helgadóttir ${ }^{5}$, Sergey Vakulenko ${ }^{7}$, Sergey Buryak ${ }^{7}$, Ögmundur Erlendsson ${ }^{5}$, Rüdiger Giese ${ }^{4}$, Jehanne P. Cavailhes ${ }^{1}$, Dougal A. Jerram ${ }^{3,8}$, Ásgrímur Guðmundsson ${ }^{9}$, Egill Júlíusson ${ }^{9}$

${ }^{1}$ Volcanic Basin Petroleum Research (VBPR), Oslo, Norway

${ }^{2}$ Department of Geology and Petroleum Geology, University of Aberdeen, UK.

${ }^{3}$ The Centre for Earth Evolution and Dynamics (CEED), Oslo, Norway.

${ }^{4}$ Helmholtz Centre Potsdam, German Research Centre for Geosciences GFZ, 14473 Potsdam, Germany

5 ÍSOR Iceland GeoSurvey, Reykjavik, Iceland

${ }^{6}$ ISOR Iceland GeoSurvey, Akureyri Branch, Iceland

${ }^{7}$ DECO Geophysical SC, MSU Science Park, Leninskie Gory 1-77, 119992 Moscow, Russia

${ }^{8}$ DougalEARTH Ltd., Solihull, UK

${ }^{9}$ Landsvirkjun, Háaleitisbraut 68, 103 Reykjavík, Iceland

Keywords: Krafla; Iceland; Geothermal; VSP; Sonic velocity; IMAGE

Abstract

The Krafla geothermal area in northern Iceland comprises one of the best studied examples of a high temperature geothermal field associated with an active volcanic rift zone. Of key importance to improved resource exploration and development in volcanic areas such as Krafla, is the interpretation and understanding of the subsurface geology. Within this study we present results from an integrated analysis of the downhole volcanic stratigraphy from the K-18 borehole within the Krafla caldera based on combined wireline, ditch cuttings, and zero-offset VSP (vertical seismic profile) analyses. This study presents the first published sonic log velocity data from a high temperature geothermal borehole in Iceland and clearly demonstrates the importance of borehole velocity data for improving volcanic facies interpretations. The shallow subsurface geology of the K-18 site from c. 0-380 m comprises an interlayered sequence of sub-aerial basaltic lavas, hyaloclastites and tuffaceous lithologies of both felsic and basic composition, which are progressively replaced by basaltic sheet intrusions with increasing depth. An interval of variably basic to more evolved mixed tuffaceous facies is identified based on cuttings analysis, gamma and sonic velocities between c. 790-1120 m depth. Discrete high sonic Vp units cut the lower c. $100 \mathrm{~m}$ of this interval and are interpreted as either sheet intrusions or lava interiors. At c. 
$1800 \mathrm{~m}$, a sharp increase in P-wave velocity from c. 4.5 to c. $5.5 \mathrm{~km} / \mathrm{s}$, represents the transition from a mixed lava and sheet intrusion dominated sequence, into a dense basic intrusion forming the local basement that persists to the bottom of the borehole at c. $2215 \mathrm{~m}$. Reduced travel time analysis of processed zero-offset VSP results reveal good correspondence with the major stratigraphic boundaries in the borehole, supporting the potential for VSP studies to robustly characterize complex volcanic stratigraphy in high temperature geothermal fields. Finally, the application of percentage-based ditch cuttings analyses methods for volcanic facies analysis in geothermal boreholes is tested and assessed to have future potential.

\section{Introduction}

Geothermal resources form a critical component of the global energy budget, and are extensively exploited within a wide range of geological settings for production of clean and often relatively cheap energy globally (Fridleifsson, 2001; Lund et al., 2005). Understanding and experience relating to the commercial development of high temperature geothermal systems has been pioneered in countries such as Iceland over the past few decades (Ármannsson et al., 1987; Guðmundsson, 2005; Flóvenz and Steingrímsson, 2009) with geothermal energy providing around 90\% of Iceland's buildings (Flóvenz and Steingrímsson, 2009), and approximately $25 \%$ of its electrical production. In Iceland, high temperature geothermal fields are associated with volcanic settings, often including systems closely linked to still active volcanic systems, such as along the Reykjanes peninsula and at the Krafla caldera, both located above onshore extensions of the Mid-Atlantic Ridge. One of the more spectacular demonstrations of this linkage was observed during the IDDP (Iceland Deep Drilling Program) at Krafla, where the IDDP-1 borehole intersected a molten rhyolitic intrusion at c. $2.1 \mathrm{~km}$ depth (Elders et al., 2014). One of the key objectives of the IDDP program was to investigate the potential for economically exploiting supercritical hydrous fluids at drillable depths (Fridleifsson and Elders, 2005). The critical point for pure water occurs at $374^{\circ} \mathrm{C}$ and $22.2 \mathrm{MPa}$ (increasing with dissolved components), and it has been estimated that the power output for a borehole utilizing supercritical fluids may produce an order of magnitude more energy than from a sub-critical conventional high temperature borehole (Fridleifsson and Elders, 2005; Elders et al., 2014; Scott et al., 2015).

An important aspect of improving exploration for high temperature and supercritical geothermal reservoirs in volcanic settings is the sub-surface sampling, imaging and interpretation of the geological conditions that host geothermal reservoirs. Imaging problems associated with heterogeneous basaltic sequences are well known from the reflection seismic and borehole literature (e.g. Pujol and Smithson, 1991; Planke, 1994; Planke et al., 2000; White et al., 2003; Nelson et al., 2009). Where possible, any seismic interpretation through volcanic successions can be further informed with other remote sensing techniques e.g. gravity, magnetics, resistivity, MT, etc. (e.g. Hautot et al., 2007; Jerram 
et al., 2009; Abdelmak et al., 2016). Where boreholes are available, further information from e.g. wireline, VSP, borehole imaging (e.g. Planke and Eldholm, 1994; Christie et al., 2006; Watton et al., 2014a; Millett et al., 2015), cuttings data (e.g. Millett et al., 2014), and in some cases core material (e.g. Watton et al., 2014b) can be incorporated. In the majority of cases, however, only some of these data will be available to base interpretations on.

Down borehole VSP (vertical seismic profile) investigations provide a potentially valuable technique for characterizing sub-surface volcanic sequences due to their resolution and depth of investigation lying in between that of surface seismic (moderate to low vertical resolution, wide lateral coverage) and wireline logging (high vertical resolution with very limited horizontal depth of investigation away from borehole). VSP experiments have been demonstrated to yield valuable information when applied within basaltic volcanic sequences including facies boundaries, faults, alteration variations, volcaniclastic and interbed lithologies, and the presence of intrusions etc. (Pujol and Smithson, 1991; Planke and Eldholm, 1994; Planke and Flóvenz, 1996; Shaw et al., 2008; Christie et al., 2006; Petersen et al., 2015). VSP techniques therefore, provide a potentially highly valuable exploration tool for volcanic geothermal fields but have, to date, not been widely tested or applied, especially for high temperature volcanic settings such as at Krafla. The Larderello geothermal field in Italy (Santilano et al., 2015), forms one notable exception where VSP has been extensively used to image deep structures (Vanorio et al., 2004).

As part of the European Union funded IMAGE project (Integrated Methods for Advanced Geothermal Exploration: http://www.image-fp7.eu), a series of zero- and far-offset vertical seismic profile (VSP) experiments were conducted within two wells, K-18 and K-26, at the Krafla high temperature geothermal field in May and June 2014 (Halldórsdóttir et al., 2014; Planke et al., 2016; Kästner et al., this volume). These experiments comprise the first of their kind for high temperature geothermal boreholes on Iceland. The goal of acquisition was to investigate the applicability of the VSP technique for imaging features such as lithological boundaries, intrusions, fracture zones and fluids to aid exploration within the heterogeneous basalt dominated subsurface sequence at the Krafla high temperature field and other similar settings.

Sonic log data was also collected within K-18 as part of the IMAGE project, comprising the first results of its kind for a high temperature geothermal borehole on Iceland (Hersir et al., 2016). Sonic $\log$ data is used extensively in volcanic borehole studies around the world and forms a vital link to lower vertical resolution VSP and seismic data (Planke, 1994; Planke et al., 1999; Nelson et al., 2009; Millett et al., 2015). Additional to wireline data, high quality ditch cuttings data is routinely utilized to inform the geological interpretation of geothermal boreholes on Iceland (Guðmundsson, 2005). As part of this study we undertook a re-evaluation of the K-18 ditch cuttings data, to test the applicability of recent 
developments in off-shore volcanic ditch cuttings analysis (e.g. Millett et al., 2014; 2015) for geothermal fields.

Within this study we present analyses of new processed zero offset VSP data, borehole sonic, borehole televiewer (BHTV), pre-existing wireline data (calliper, gamma, neutron and resistivity logs) and new ditch cuttings analysis for the K-18 borehole. The objective of this study is to create a robust integrated geological interpretation of the K-18 borehole. Developments in volcanic ditch cuttings analysis are presented and discussed along with an appraisal of the importance of sonic log velocity data for volcanic borehole analysis. Importantly, our study demonstrates that zero-offset VSP data can effectively image complex volcanic sequences in high temperature geothermal settings. Our results lend strong support for further testing and the future deployment of the VSP technique as an exploration technique in high temperature volcanic geothermal settings on Iceland and elsewhere.

\section{Geological setting}

The Krafla high temperature geothermal area is situated in Iceland's northern volcanic zone, which comprises the on-land extension of the Kolbeinsey Ridge (Figure 1). The Kolbeinsey Ridge in turn represents a segment of the Mid Atlantic Ridge and the centre of spreading between the NW European and E Greenland conjugate rifted continental margins. The Krafla area is believed to have been active for at least the last 200,000 years and is dominated by an active central volcano with two associated caldera structures, which is intersected by a NE-SW to N-S oriented fault and fissure swarm system with different rift opening directions, due east, north of the caldera, and due SE, south of the caldera (Sæmundsson, 1991). The fissure swarm crossing the centre has widened by some tenths of meters every ten thousand years, resulting in the oblique-elliptical shape of the caldera (Sæmundsson, 1991).

The volcanic activity at Krafla is episodic and basalt dominated although more evolved eruptions and magmas are also well documented (Sæmundsson, 1991; Tuffen and Castro, 2008; Elders et al., 2014). Eruptions occur at 250-1000 year intervals, each episode lasting 10 to 20 years (Ármannsson et al., 1987). The magma chamber and source for the geothermal system, was identified at c. 3-8 km depth by geophysical analyses during the 1975-1984 'Krafla Fires' volcanic activity (Einarsson, 1978). The oldest exposed rocks in the Krafla central volcano are hyaloclastites from the 2nd to last glaciation (e.g. younger than 190,000 years) that probably overlay complex lava flow series (>190,000 years) that are exposed at Reykjahlíðsheiði and Grímsstaðaheiði (Sæmundsson, 1991). During the following interglacial period, the Eem interglacial (126,000-115,000 years), extensive areal lava flows and terrestrial land topography were typical, which is covered by explosive rhyolitic deposits caused by large scale eruptions during the early stages of the Weichsel ice age $(115,000-60,000$ years $)$ 
136 (Sæmundsson, 1991). These events are believed to have caused the formation of the inner caldera of 8 137 by $10 \mathrm{~km}$ width around 80,000 years ago.

138 During the last glaciation, the caldera was dominantly filled with sub-glacial volcanics and subsided c. $100 \mathrm{~m}$ (Ármannsson et al., 1987). The dominant features within the caldera fill are 140 hyaloclastite ridges oriented parallel to the fissure swarm and finally by post-glacial lava flows 141 (Ármannsson et al., 1987). The Víti explosive crater formed in 1724 at the beginning of the Mývatn 142 Fires eruptive episode and is the youngest volcanic feature within the Geothermal field area 143 (Sæmundsson, 1991). Approximately 1500-2000 $\mathrm{m}$ of subsurface volcanic strata within the inner 144 caldera have no surface expression. An extensional WNW-ESE low gravity lineament described by 145 Árnason et al. (2008), and Weisenberger et al. (2015) is believed to have been mostly filled with hyaloclastites prior to the events observed at the surface present day.

Numerous fumaroles along with extensive surface alteration within the Krafla caldera triggered systematic geothermal exploration of the area in 1970 with surface followed by subsurface exploration (Ármannsson et al., 1987). Exploration drilling started in 1974 and led to the development of the field and today a 60 MW power plant is operated from the Krafla geothermal field (Nielsen et al., 2000; Flóvenz and Steingrímsson, 2009).

A mixed sequence of lavas and hyaloclastites are encountered below surface of the Krafla field down to ca. $1.5 \mathrm{~km}$, which are progressively replaced by a dominantly intruded sequence below this depth. The subsurface sequence is also dominated by basaltic compositions but occurrences of more evolved intrusive granophyres and felsites are also recorded within the intruded sequence (Mortensen et al., 2014). Scientific deep drilling in the Krafla caldera (IDDP Iceland Deep Drilling Project) was undertaken in 2008 to investigate the existence and production potential of zones of super critical fluids (Friðleifsson et al., 2013). The well encountered rhyolitic magma at a depth of c. $2.1 \mathrm{~km}$ (Mortensen et al., 2014). Magmatic gas influxes to the geothermal system during the Krafla Fires and at other times have significantly contaminated the water compositions of parts of the geothermal system causing deposition and corrosion in production wells (Ármannsson et al., 1987).

\section{Data and methods}

The K-18 borehole is located within the Krafla caldera (Figure 2) and was drilled in the eastern part of the geothermal field in 1981. The borehole is c. $2215 \mathrm{~m}$ deep and cased to $663 \mathrm{~m}$. K-18 was drilled with deviation not exceeding $1-2^{\circ}$ from vertical, resulting in $<20 \mathrm{~m}$ total horizontal shift between the top and bottom of the well (Árnadóttir, 2014). The borehole did not encounter any productive feed zones, testing only smaller scale feed zones (Guðmundsson, 1981). The temperature of the K-18 well is also significantly lower than in neighbouring wells (e.g. K-17) suggesting a barrier to fluid 
connectivity between these sites. For these reasons, the K-18 well was never brought online as a production well. The geology encountered within the well comprises a mixture of lava flows and mixed volcaniclastic/hyaloclastite facies that becomes increasingly dominated by intrusions with depth (Ármannsson et al., 1987).

Washed and dried ditch cuttings, sonic log P-wave velocity, resistivity (deep 64" and shallow 16"), gamma ray, caliper, neutron counts and acoustic televiewer logs, along with zero offset VSP velocity data were available for this study (Table 1). Throughout this paper we have defined sections of stratigraphy with similar properties for each of the separate methods in, order to aid discussion in the text. Cuttings intervals with similar properties are divided into cuttings Groups 1-8, wireline log intervals are referred to as Units 1-5 along with sub-units, and VSP RTT (reduced travel time) intervals are referred to as Intervals L1-L10. The basis for these divisions are outlined in detail within the results section. In the remainder of this section, a description of the specific analysis and methodologies used to inform this contribution are presented.

\subsection{Ditch cuttings analysis}

Washed and dried ditch cuttings (small rock chips from the drill bit returned to the surface via the drilling fluid), collected at $2 \mathrm{~m}$ intervals during drilling, were available for assessment for the entire borehole. Cuttings analysis was undertaken during drilling of the original well in 1981 (Guðmundsson et al., 1981), as is standard practice on Iceland. The purpose of reanalysing the well was to appraise the applicability of recent developments in volcanic ditch cuttings analysis (e.g. Millett et al., 2014; 2015), developed from offshore boreholes, to K-18 and volcanic geothermal wells in general. The focus of the study was to investigate the volcanic facies encountered in the borehole. The wide range of temperature diagnostic alteration minerals, used to identify the sub-surface thermal conditions of geothermal fields, is not investigated in this study, and for these, the original report is consulted (Guðmundsson et al., 1981).

Ditch cuttings samples may incorporate many artefacts during the drilling and recovery process relating to drill bit variations, rate of penetration, differing competency of lithologies, cavings, mixing and time lags in transport etc. (Figure 3). In order to account for some of these challenges, the classification scheme of Millett et al. (2014) is utilized within this study which involves a non-genetic percentage based recording system based on the ternary diagram presented in Figure 4. Recovered cuttings assemblages are divided into the broad end-members: 1. crystalline/scoriaceous, 2 . volcanic glass, and 3. epiclastic / bole, which at the basic level should include all cuttings populations derived from a volcanic sequence. One key advantage of this system of recording is that log style outputs can be generated and compared to associated wireline log signatures prior to a genetic interpretation of the assemblage. This basic form of analysis can then be complemented by more detailed observations 
(texture, mineralogy, alteration, etc.) and associated interpretations, as permitted by time during operations and / or cuttings quality. Importantly, the system reduces the dependence on an interpretation based method of recording primary observations/data, which can limit the potential for later reappraisal and inter-well correlation.

Within the present study, the crystalline and volcanic glass end members have been sub-divided into three components each to better inform the facies assessment based on the recovered material. The crystalline end member is divided into crystalline basalt, vesicular and leucocratic, and the glass end member is split into glass, vesicular, and tuffaceous/pumice. Leucocratic crystalline material within this study refers to pale coloured cuttings relative to fresh basalt properties and at the basic level includes both more evolved compositions along with samples that may have been chloritized or leached, the distinction potentially requiring petrography depending on the case. Figure 4 displays an example interval of the raw output from the K-18 cuttings analysis. For the purposes of this study a subjective $0-5$ scale (zero to complete alteration) was also included for each assemblage but it is noted that the scheme is flexible and any feature or index can be added easily such as index alteration minerals, detailed crystal size assessment or oxidation percent. The detail and scope of analysis and data recording possible for each depth interval are intimately linked to time, and therefore, the strategy for analysis must be tailored differently e.g. for real-time ROP (rate of penetration) dependent analysis compared to post-well less time pressured analysis. The cuttings analyses presented within this contribution, although undertaken post-drilling, included only five days of analysis, making the depth of investigation restricted accordingly.

\subsection{Wireline data}

A range of wireline log data, both from the initial logging of K-18 in 1981, and from the IMAGE funded VSP experiments in 2014, were made available for this study (Table 1). Wireline profile analysis through the K-18 borehole facies was undertaken with reference to the extensive literature on volcanic wireline responses (e.g. Planke, 1994; Planke and Cambray, 1998; Helm-Clark et al., 2004; Bartetzko et al., 2005; Nelson et al., 2009; Watton et al., 2014a; Millett et al., 2015). Of key focus was the newly acquired sonic log data for K-18, acquired using a Robertson Geologging (RG-LSS) Slim Full-Waveform Sonic tool which continuously logged the open-hole section (c 660-2170 m) (Hersir et al., 2016). During acquisition, transit times were derived from automatically picked travel times using a first-arrival edge detection based on a standard threshold method. In subsequent processing, a depthderived borehole compensation yielded the compensated transit times of the compressional first arrivals $(\mu \mathrm{s} / \mathrm{ft})$, which were converted to seismic P-wave velocities $(\mathrm{km} / \mathrm{s})$, which will be presented throughout this contribution.

Neutron log data was recorded in the upper section above c. $663 \mathrm{~m}$ prior to casing, but no sonic $\log$ data was collected within that interval, therefore to gain insight into the likely velocity structure of 
the shallow borehole, the relationship between neutron and sonic data from the open hole section was used to predict the sonic response for the cased section of the borehole. The neutron log measures the attenuation and capturing of emitted high-energy neutrons, between a source and receiver, by the formation. Hydrogen has the greatest effect on neutron capture hence the volume of $\mathrm{H}_{2} \mathrm{O}$ within a formation has a predictable effect on the resulting neutron count (API) for known matrix compositions and can be calibrated to give porosity. However, neutron log data cannot be used to estimate porosity directly for altered volcanic rocks, where many alteration and secondary mineral species contain bound or structural water, e.g. clays and zeolites, which would require comprehensive XRD data analysis for neutron log calibration (e.g. Broglia and Ellis, 1990). The neutron data is therefore presented as API counts within this contribution and the general relationship that API counts reduce with increasing porosity and hydrous alteration products.

Figure 5 displays compressional velocity $\mathrm{Vp}(\mathrm{km} / \mathrm{s})$ versus neutron (API) for the open hole section of K-18, with a clear positive correlation, albeit with significant scatter between the two properties. A manually fitted composite linear function gives a closer fit to the data spread than a single logarithmic fit, especially at the lower and higher API ranges (Millett et al., 2016a). The use of a manual fitting approach to the data is justified due to the wide range of facies with different intrinsic properties and data ranges along with the alteration effects described above (Figure 5a), that are incorporated within the open borehole section. This was then then used to give an indication of the Vp response of the cased interval for comparison to the VSP.

The gamma ray logging tool measures the natural radioactivity of the formation, which is dependent on the abundance of the naturally occurring elements $\mathrm{K}$, Th, and $\mathrm{U}$. In volcanic rocks the, gamma response is linked to composition whereby, in general, the more evolved a volcanic rock is along the path from basalt to rhyolite, the higher the gamma response (Steffanson et al., 2000). This is due to these elements being generally incompatible with early mineralizing phases in a basaltic melt, and therefore, become enriched in the residual liquid. Basalt has a generally very low gamma response, but may increase slightly due to alteration (e.g. Planke, 1994).

The resistivity log measures how resistive a formation is to an applied electrical current. In general, hydrous pore fluids comprise conductors whilst many silicate minerals associated with a rocks matrix comprise resistors. In the same way that mineral bound water complicates the neutron $\log$ signature, bound water may also reduce resistivity readings especially for the deep resistivity log. Shallow (16 inch spacing) and deep resistivity (64 inch spacing) measurements from a dual-spacing normal-electrode tool were used for this study. Time-lapse resistivity measurements were also made in the K-18 borehole as it heated up naturally in the weeks after being cooled for the VSP experiment as part of the IMAGE project (Vilhjálmsson et al., 2016). The results of this study clearly demonstrate the 
temperature dependence of resistivity and form a promising provisional guide for calibrating bedrock resistivity tool measurements in variable temperature geothermal borehole investigations.

Finally, as part of the IMAGE project the effect of the cation exchange capacity (CEC) on resistivity of rocks in geothermal systems was measured in well K-18 (Weisenberger et al., 2016). The CEC measurements show that the low resistivity in the electrical resistivity logs coincide with high CEC values (> $5 \mathrm{meq} / 100 \mathrm{~g}$ ). At the facies boundary between the mixed-layer clay and epidote-chlorite zone the CEC drops below $\sim 5 \mathrm{meq} / 100 \mathrm{~g}$ and decreases slowly with increasing depth. The facies boundary overlap with the transition where resistivity logs show an increase in resistivity.

\subsection{Borehole televiewer}

Acoustic borehole image logging was performed in the K-18 borehole between 470-2180 m measured depths (MD) with the API-43 (ALT) Borehole Televiewer (BHTV) tool on October the 10th in 2014 as a part of the IMAGE project (Árnadóttir, 2014; Blischke et al., 2016). BHTV logging can provide high resolution acoustic images of open borehole sections making it a highly valuable tool for conducting structural and facies analysis by revealing fractures, formation boundaries, bedding or foliation of lithological units, facies types, along with estimates of the formation tightness. The identification of possible fracture systems is performed by a qualitative characterisation of the orientation and inclination of natural fracture and fault systems that are observed in the borehole. Drilling induced fractures (tensile fractures) and borehole break-outs can also be imaged, which may reveal the orientation of principle active stresses around the borehole (Zoback et al., 1985).

Data processing and interpretation were performed in the petro-physical and borehole data analysis program WellCAD (version 4.4 build 3303). The image data were oriented at import time to magnetic north and subsequently rotated by $12.52^{\circ} \mathrm{W}$, to correct for the magnetic declination applicable for the logging date. The BHTV logging operations were challenging due high downhole temperatures and the rapid re-heating of the borehole. Subsequently data quality was not optimal due to the requirement to run the log quickly, requiring a lower tool resolution setting (72 pixels per rotation), in order to attempt to keep the tool within its operational temperature limits $\left(<125^{\circ} \mathrm{C}\right)$. A detailed summary of the tool settings and logging operations can be found in Blischke et al. (2016).

\subsection{Zero offset vertical seismic profile}

Vertical seismic profiling (VSP) is a borehole seismic method combining seismic sources at the surface with receivers (e.g., geophones) placed inside a borehole. Depending on the survey geometry, different processing schemes are applied. It can provide both elastic and structural properties of the subsurface (around the borehole) with, compared to surface seismic, higher spatial resolution.

The VSP survey at the Krafla geothermal field encompassed a set of test experiments including zero-, far-, and multi-offset three-component VSP data recorded from within two boreholes (K-18 and 
K-26, Planke et al., 2016; Kästner et al., this volume) located in the geothermal field. Within this study, only the zero-offset VSP data measured utilizing specially constructed air-gun pits at the K-18 borehole are investigated.

Detailed information regarding the survey setup (see Halldórsdóttir et al., 2014) and processing of a subset of the VSP experiments at Krafla are included within the contribution by Kästner et al. (this volume), and also within the processing report (Vakulenko and Buryak, 2016), delivered as part of the IMAGE project (see also Planke et al., 2016). In this paper we only consider the zero-offset VSP data recorded in well K-18 (Figure 6). The air-gun source pit was located $29 \mathrm{~m}$ away from the well head of the K-18 borehole. For the purposes of this study, first-break arrival times (FB in ms) were picked for the P-wave and S-wave first arrivals and, along with the offset corrected horizontal source to borehole distances (D), provided by Deco (Vakulenko and Buryak, 2016). P- and S-wave velocity profiles were calculated along the well and are used for all subsequently presented VSP data.

\section{Results}

\subsection{Ditch cuttings}

Figure 7 displays a summary of the percentage based cuttings analyses for the K-18 borehole alongside the original cuttings analyses. The percentage logs display clear variations in the abundance of glass, crystalline and epiclastic material throughout the penetrated borehole interval, along with extensive mixing of these end members in many cases. From these curves, intervals dominated by one or a combination of characteristic cuttings populations have been separated into eight broad groups (Figure 7). A summary geological interpretation, based solely on the cuttings assemblages is also presented.

The K-18 borehole is dominated by basaltic crystalline cuttings, which comprises the main lithology for c. $1500 \mathrm{~m}$ of the c. $2200 \mathrm{~m}$ well penetration. Glass or alteration products of glass comprise a significant proportion of the retrieved material over three main intervals (beginning at c. 50, c. 800 and c. 1590 m respectively; Figure 7) which account for the remaining stratigraphy. Epiclastic material is only present at percentages above c. $25 \%$ in three short $(<10 \mathrm{~m})$ intervals in the upper $385 \mathrm{~m}$ of the borehole. The presence of intervals dominated by alteration products, with no remaining primary constituents, forms a key challenge for any classification scheme in geothermal boreholes. In the present study, alteration products dominantly in the form of clays were assigned to the 'glass' column, where some remnant textures of e.g. glass shards or pumice textures were identified within the assemblage. However, in cases where limited to no remnant facies textures could be deduced, especially from more extremely altered examples deeper in the borehole (below c. $400 \mathrm{~m}$ ), assignment of an end member in the facies scheme incorporates undesirable interpretation into the raw data generation. At the time of 
analyses, these constituents were included within the glass end-member, however, a possible future solution may be to incorporate an additional percentage group for altered cuttings of undefined textural origin.

\section{Depth interval 0-385 m}

The cuttings response over the first c. $385 \mathrm{~m}$ of K-18 comprise high resolution alternating sequences of crystalline, glass, and epiclastic dominated units. The first c. $70 \mathrm{~m}$ of the borehole comprises fresh to weakly altered very fine to medium crystalline basalt in blocky to sub-angular cuttings with minor restricted intervals of increased glass e.g. c. $50 \mathrm{~m}$. The cuttings are mostly weakly to non-vesicular but become highly vesicular in places and display dispersed oxidation reddening. This interval transitions abruptly into a mixed glass and crystalline assemblage below $70 \mathrm{~m}$, with the dark black bright lustre glass dominated by weakly vesicular glass cuttings. Both glass and crystalline cuttings display variable alteration from minor to complete but are in general relatively fresh (Figure 8a). At c. $110 \mathrm{~m}$ a sharp increase in the abundance of blocky to shard-like consolidated volcaniclastic silt to fine sand grade cuttings is encountered for c.10 m (Figure $8 \mathrm{~b}$ ). This in turn is followed by a return to a crystalline dominated sequence with minor glass before a return to a similar thin volcaniclastic unit at c. $140 \mathrm{~m}$.

At c. $145 \mathrm{~m}$ a distinct cemented tuffaceous interval comprising highly vesicular pyroclastic shards in blocky to sub-angular cuttings occurs (Figure 8c). Intricate interstitial original pore space is filled with secondary precipitates. This sequence is replaced at c. $190 \mathrm{~m}$ depth by a short variably vesicular crystalline basalt dominated sequence prior to a heterogeneous mixed glass and basalt sequence from c. 208-260 m. In some instances, hyaloclastite, comprising fresh blocky tachylitic glass shards within a dull lustre altered glass/palagonite matrix is identified (Figure 8d). Within this interval, the first occurrence of highly vesicular crystalline scoriaceous cuttings occur in two short intervals (Figure 8e). This sequence is in turn replaced by a highly vesicular glass dominated sequence from c. 260-282 m.

From $282 \mathrm{~m}$ to $340 \mathrm{~m}$ the section is dominated by crystalline scoriaceous material with smectite clay coatings on most vesicle walls. This sequence is in turn replaced by a further mixed glass and crystalline sequence with two minor volcaniclastic intervals at c. $356 \mathrm{~m}$ and c. $376 \mathrm{~m}$. Throughout this upper sequence, very short excursions of either glass or vesicular crystalline cuttings (or both) were recorded as thin boundaries (Group 3 in Figure 7), but it should be stated that in many of these cases, the cuttings facies type had been encountered higher in the borehole and so a contribution from cavings cannot be excluded.

\section{Depth interval 385-800 m}


The K-18 interval between $385-800 \mathrm{~m}$ is relatively uniform and largely comprises fresh to weakly altered fine to medium crystalline basalt. Within the interval, a small number of horizons with slightly increased percentages of vesicular basalt and/or alteration are observed which may represent lava flow boundaries. Increased volumes of pale green grey crystalline material are also common but in most cases appear to relate to alteration. At c. $574 \mathrm{~m}$ however, a different type of leucocratic material is observed which is pale, finely crystalline and includes evenly distributed small dark oxides and may represent a more evolved composition.

The interval between $800-1120 \mathrm{~m}$ of the K-18 well comprises a sequence of pale leucocratic volcanic material punctuated with layers of increased percentages of fresh dark crystalline basalt in the lower half of the interval from c. 965-1120 m (Figure 8f-h). The pale material comprises a heterogeneous mixture of pale crystalline to clay grade cuttings with clear evidence for remnant glass / pumice textures in places (Figure 8f). In some instances, remnant zoned glass shards may be identified typical of altered hyaloclastite, however, the majority of the material is either deeply altered with no primary textures or leucocratic crystalline. In the cases where remnant pumice textures are observed, there is no discernible difference in terms of matrix composition/appearance between these cuttings and the pale clay dominated cuttings with no clear primary textures (Figure $8 \mathrm{f}$ ). These cuttings were, therefore, all included in the pumice percentage log for the purposes of this study, as a best estimate of their original nature. This assumption is plausible due to the much higher susceptibility of volcanic glass to complete and pervasive alteration compared to crystalline units (Franzon et al., 2001; 2010), however, this incorporates a high degree of uncertainty as discussed above.

The transition out of the leucocratic sequence is gradual and comprises a return to a sequence dominated by fine to medium crystalline basalt showing variable degrees of alteration from fresh to pervasive. The degree of alteration is recorded both in the subjective alteration index and by inference in the abundance of leucocratic crystalline material (Figure 7). Within the sequence minor evidence for altered glass is observed in a small number of cases, however, these cuttings are never observed in abundances above that which could easily represent cavings from higher in the borehole (Millett et al., 2014). Some leucocratic crystalline material is observed, however, the majority of instances are inferred to represent alteration aside from one example at c. $1480 \mathrm{~m}$, which may again represent potentially more evolved compositions similar in character to that identified higher in the borehole (c. $574 \mathrm{~m}$ ). A distinct lack of vesicular crystalline basalt suggests that the sequence is dominated by intrusions as opposed to lavas, however, some lava host rock probably exists within the sequence. 
The interval between 1590-1690 m comprises a sequence of pale highly altered cuttings punctuated by cyclical percentage increases of fresher crystalline basalt cuttings. The cuttings comprise green grey to grey mottled clays with irregularly dispersed darker spherical blebs. In some cases, weak traces of pumice type textures may be seen, however, the degree to which secondary mineral growth is the cause of these features remains poorly constrained due to the pervasive and complete replacement of the original minerals or glass within these cuttings. The non-crystalline cuttings are recorded in the glass column, similar to the approach outlined for the interval 800-1120 m.

The remainder of the borehole penetration from 1690-2200 m comprises a relatively uniform sequence dominated by fresh to weakly altered crystalline basalt. There are indications of increased crystal size ranging from medium up to coarse, potentially suggesting the presence of dolerite or gabbroic bodies. At the beginning of this section at c. $1700 \mathrm{~m}$, a short interval of distinct leucocratic crystalline material is encountered. The fresh medium crystalline material displays a brighter lustre than the surrounding basaltic rocks and appears to potentially contain free quartz. Again, a lack of any vesicular basalt remnants appears to preclude any significant lava flow component within this interval, supporting a densely intruded nature of the interval.

\subsection{Wireline logs}

A composite log of selected wireline data for K-18 is presented in Figure 9. Six broad stratigraphic units along with sub-groups have been defined for the K-18 borehole, each comprising intervals of similar properties (Figure 9). Units 4,5,6 and the lower part of Unit 3 have been defined based on full wireline log suite characteristics supported by cuttings inferences, whilst units 1,2 and the upper part of Unit 3 from the cased section of K-18 $(0-660 \mathrm{~m})$ are based on resistivity and neutron counts in conjunction with the cuttings analysis, where gamma ray and sonic velocity data are not available.

Unit $1(0-80 \mathrm{~m})$

Almost no log data exists for the upper $80 \mathrm{~m}$ of the well and therefore the variably vesicular basalt nature of the cuttings provide the only real inference as to the volcanic facies. Resistivity data is deemed poorly constrained due to the interval being above the water table.

Unit $2(80-380 \mathrm{~m})$

Unit 2 also has very limited $\log$ data. The data that is present displays variable but relatively low resistivities and consistently higher apparent porosities (low API) from the neutron counts data. Variable calliper responses in the upper part of the unit also suggest unstable formation and cavings 
which may have added to the variability in the log data. The lower limit has been defined from the neutron counts curve which display a decrease in apparent porosity (increase in neutron counts) consistent with the denser crystalline lithology of the underlying Unit 3. The upper limit is defined based on the cuttings description, as limited wireline data is available at this depth. It is noted that wide lithological heterogeneity is encountered within the cuttings for this section and therefore the log unit does not define a simple facies association.

Unit $3(380-790 \mathrm{~m})$

Unit 3 is defined largely based on the sonic velocity and the neutron count curves, both of which show a distinct and sharp relative decrease to define the lower limit of the unit. Unit 3 is interpreted to comprises a sequence of lavas, intruded by non-vesicular sheet intrusions towards its base. The upper limit is defined by a prominent peak in the resistivity and neutron curves representing a denser flow interior or possible sheet intrusion. A general increase in resistivity with depth is observed over the Unit 3 interval whereas the neutron values display a serrated profile dominated by relatively low apparent porosity. The increase in average resistivity with depth may relate to a higher proportion of the wellbeing intruded in the lower part of this sequence, as is inferred from the cuttings analysis, with the closure of fractures due to combined overburden and secondary mineralization also potentially contributing factors. Velocity data only exists for the lower portion of Unit 3 which displays relatively high velocities, with an average velocity of $4.9 \pm 0.5 \mathrm{~km} / \mathrm{s}$.

Unit 4 corresponds to the mixed leucocratic interval identified from the cuttings analysis, for which there is a very close correspondence. The lower limit of Unit 4 has been defined based on the sonic velocity $\log$, where the average values show a distinct increase from c. 3.5 up to c. $4.2 \mathrm{~km} / \mathrm{s}$. Unit 4 has been sub-divided into two sub-units, $4 \mathrm{a}$ and $4 \mathrm{~b}$, based on $\mathrm{Vp}$ and gamma data. The boundary between the two sub-units is defined by the base of a prominent high gamma interval within sub-unit $4 \mathrm{a}(\mathrm{c} .880-960 \mathrm{~m})$.

Sub-unit 4a displays a relatively uniform low $\mathrm{Vp}$ with an average of $2.7 \mathrm{~km} / \mathrm{s}$, with correspondingly uniform moderate resistivity and high neutron porosity. Two distinct gamma intervals including an upper low gamma interval (c. 790-880 m, average 17 API) overlying a moderate to high gamma interval (c. 880-960 m, average c. 39 API) are present. A lack of any correspondence between the gamma and velocity data appears to preclude an intrusive origin for the high gamma interval (Delpino and Bermúdez, 2009). Sub-unit 4a is therefore inferred to comprises a compositionally zoned highly altered tuffaceous sequence. 
remains relatively constant but at slightly higher values compared to sub-unit $4 \mathrm{a}$, whilst neutron count values show little variation. One major exception to this trend occurs near the top of the sub-unit (c. $980 \mathrm{~m}$ ) where the highest velocity interval corresponds very clearly to increased resistivity and significantly lower neutron porosity. The majority of sub-unit $4 \mathrm{~b}$ displays low gamma values (average c. 20 API), similar to the upper part of sub-unit 4a, however, a small number of short gamma peaks are recorded in the lower half of the unit. The velocity characteristics of sub-unit $4 \mathrm{~b}$ specifically highlight the utility of the sonic log, whereby the other logs only clearly identify one of the high Vp layers. The identification of multiple high $\mathrm{Vp}$ layers within the section is consistent either with intrusions or the presence of dense lava flow interiors. A lack of either clear asymmetric log profiles (lavas; Planke, 1994) or box-like profiles (sheet intrusions, Planke et al., 2000), makes further distinctions challenging, with a distinct lack of vesicular basaltic cuttings potentially preferentially supporting an intrusive origin.

Unit $5(1120-1880 \mathrm{~m})$

Unit 5 comprises a crystalline basalt dominated sequence with its base defined by a distinct increase in average velocity at c. $1880 \mathrm{~m}$. The unit has been sub-divided into 7 sub-units, based on a combination of wireline data and associated ditch cuttings inference. The velocity of Unit 5 ranges from 2.4 to $5.9 \mathrm{~km} / \mathrm{s}$ with an average velocity of $4.5 \mathrm{~km} / \mathrm{s}$. Intervals dominated by crystalline basalt $(5 \mathrm{a}, 5 \mathrm{~b}$, $5 \mathrm{e}$ and $5 \mathrm{~g}$ ) have high average velocities, ranging from c. 4 to $4.7 \mathrm{~km} / \mathrm{s}$ average sonic velocities. Subunit $5 \mathrm{c}$ comprises mixed crystalline basalt and highly altered leucocratic cuttings inferred to be tuffaceous in origin. Somewhat surprisingly, there appears to be very little change in the character of the velocity (average $4.5 \mathrm{~km} / \mathrm{s}$ ) or other log data for sub-unit $5 \mathrm{c}$ compared to sub-unit $5 \mathrm{~b}$. A very minor reduction in velocity at the top of the section is significantly less pronounced than in the overlying altered tuffaceous sequence. We interpret this interval to comprise a densely compacted and highly altered hyaloclastite or tuffaceous facies interval. A combination of burial compaction, and pervasive alteration including precipitation of high density and Vp minerals such as epidote and actinolite (both observed within this section), during high temperature alteration of the interval, appear to have increased the Vp of the interval, similar to results identified by Frolova et al. (2005) for densely altered hyaloclastite.

Sub-units $5 \mathrm{~d}$ and $5 \mathrm{f}$ comprise two thin layers (c. $15 \mathrm{~m}$ ) showing a sharp decrease in sonic velocities (average sonic velocities are respectively 3.4 and $3.9 \mathrm{~km} / \mathrm{s}$ ) which are tightly correlated to two of the highest gamma ray peaks of the well penetration. Neither unit corresponds to a clear cuttings response, although, due to the depth of penetration and transport mixing, thin layers such as these may commonly have very little to no representation, especially if the facies is soft (Millett et al., 2014). The low velocities appear at odds with an evolved intrusive origin, unless perhaps the intrusions were subsequently completely altered. The intervals are therefore inferred to represent either altered / highly mineralized fracture zones or thin evolved tuffaceous layers. 

and 5f. It displays uniform low gamma, high resistivity and low neutron log characteristics similar to the underlying sub-unit 5g. Both of these sub-units are interpreted as basaltic composition intrusive facies.

Unit $6(1880-2200 \mathrm{~m})$

Unit 6 is composed of crystalline basalt material and shows relatively limited alteration from the cuttings data. The upper boundary is marked by a clear increase in the sonic velocities (average c. $5.6 \mathrm{~km} / \mathrm{s}$ ) and resistivity coupled with a decrease in neutron porosity. A small number of lower velocity troughs most likely represent fractures within the intrusive complex. The low gamma responses, coupled with other logs and the cuttings data suggest that this interval comprises a dense basaltic composition intrusion of either dolerite or potentially gabbro.

\subsection{Borehole televiewer}

Figure 10 displays a summary of key results from the BHTV structural analysis of the K-18 borehole. The BHTV caliper log reveals generally good hole conditions, aside for a section directly below the casing at c. $700 \mathrm{~m}$ and below the crystalline basalt section that ends at c. $795 \mathrm{~m}$. The structural interpretation shows a good correlation of small fractured and broken zone between 700-900 m, with several small feed zones and a lower neutron log response. Overall small scale and non-transmissive fracturing can be seen for most of the borehole, except for the depth interval c. 1200-1450 m, which yielded poor quality data. No major open fractures were observed within the logged interval, which is consistent with the generally low permeability in the borehole. However, two broken zones were encountered at c. 768 and c. $1253 \mathrm{~m}$, both dipping due NW with a NE-SW strike. The former possibly indicating a small fault intersection that is not connected to an intrusion complex, while the latter lies within an intrusion complex. The interpreted closed fracture network dips near vertical to the ESE and partially to the NW, whereas the partially open aperture fractures strike near N-S and dip due E.

The bulk of the logged joints and fractures are tight or closed by alteration minerals, dipping primarily in an E to ESE direction, which fits well with the inferred NNE $\left(17^{\circ} \pm 39^{\circ}\right)$ direction of the maximum horizontal stress (Ziegler et al., 2016). Drilling induced break-outs and joints are identified within K-18 and reveal a $\sigma \mathrm{h}$ (max.) orientation of $15.5^{\circ} \pm 14^{\circ}$ and are therefore consistent with the analysis by Ziegler et al. (2016).

Bedding boundaries and interfaces were also identified primarily dipping towards the SW albeit with a large multi-directional scatter. Identified intrusive contacts primarily strike NE-SW, dipping sub 542 vertically towards the NW and SE and are inferred to represent dikes, however, a small number of sub543 horizontal events, striking c. WSW-ENE and dipping c. S-SSE, possibly indicate the presence of sill 544 intrusions. The latter are in some cases non-planar, which may suggest that magma intruded a still 
unsolidified intrusive material. Sub-horizontal interfaces that were observed towards the base of the borehole at c. $2150 \mathrm{~m}$, generally dip c. $30^{\circ}$ towards SSW and appear related to sill intrusions.

\subsection{VSP results (RTT/VSP facies)}

The processed zero-offset VSP data for the K-18 borehole are presented in this section. First break arrival times (FB in $\mathrm{ms}$ ) representing the $\mathrm{P}$-wave and $\mathrm{S}$-wave first arrivals are used along with offset-corrected source to receiver distances (D) as outlined in the methods section.

Figure 11 displays a plot of reduced travel time (RTT) for the VSP Vp first break data which aids in highlighting velocity variations within the borehole. A reduction velocity of $4 \mathrm{~km} / \mathrm{s}$ is used and the reduced travel times were calculated as (FB1-FB2)/4 for FB intervals corresponding to $\mathrm{D}=5 \mathrm{~m}$ for the offset corrected Vp FB picks. RTT versus depth plots are useful as they reveal the following information:

1. Constant RTT values with depth: interval with reduction velocity

2. Linear gradient increasing with depth: interval slower than reduction velocity

3. Linear gradient decreasing with depth: interval faster than reduction velocity

4. Curved gradients: increasing or reducing velocity within interval

5. Inflections, scatter or short wavelength variance: strong impedance boundaries, local heterogeneity and dipping features such as dikes or fractures

In K-18, the RTT displays a number of clear transitions between intervals with largely linear average velocity trends, along with a number of narrow intervals of inflection and scattering points. Based on these variations in Vp RTT, ten broad VSP intervals (L1 to L10) have been defined for well K-18 (Figure 11). These intervals are interpreted to correspond to lithological successions with relatively consistent average velocities (Table 2). The transitions between these intervals vary from strong gradient changes, as for example between L1 to L2 and L6 to L7, to less pronounced changes as for L5 to L6. Interval L8 comprises a short heterogeneous interval with a rapid +/-/+ shift away from the background decreasing gradient.

Using the intervals defined from the VSP RTT, averaged interval velocities are calculated for $\mathrm{Vp}$, Vs along with the $\mathrm{Vp} / \mathrm{Vs}$ ratios and compared to the sonic log and neutron derived sonic interval velocities (Table 2). The average sonic velocity in the uncased interval of K-18 (660-2165 m) is 4.43 $\mathrm{km} / \mathrm{s}$, whereas the velocity of the first P-wave arrival from the VSP is $8.2 \%$ higher $(4.82 \mathrm{~km} / \mathrm{s})$. Interval velocities in layers interpreted from reduced travel time plots give up to $24 \%$ higher velocities from the VSP data compared to the sonic log data. The velocity difference is likely due to the increased borehole condition dependency of the sonic log data, whereby strength and fracturing variations associated with different volcanic facies can lead to strong borehole variability (e.g. Millett et al., 
2016b), such as is seen in the softer logging Unit 4 borehole sections. Dikes may also potentially act as high-velocity wave-guides for the lower frequency VSP data as suggested by synthetic modelling (Planke and Flóvenz, 1996). The neutron derived average velocities also shows a close fit to the VSP data +/- c. $0.6 \mathrm{~km} / \mathrm{s}$. RTT from VSP S-wave data was also calculated using a reduction velocity of 2.35 $\mathrm{km} / \mathrm{s}$ for comparison to the Vp RTT results (not shown) which shows generally good correspondence to the Vp RTT inflections.

The majority of the main interval transitions derived from the VSP RTT analysis correspond very closely to the major wireline log unit boundaries interpreted for the K-18 borehole. These logging units in turn correspond to major lithological boundaries based on the geological model for K-18. However, not all the interval boundaries from the VSP RTT analysis correspond to clear boundaries from the geological model, as for instance the lower boundary of L5 and L9, which both occur c. $80 \mathrm{~m}$ and c. $30 \mathrm{~m}$ above the nearest major boundaries observed from the geological model. The integration of the VSP data with the borehole geological model will be discussed further in the following section.

\section{Discussion}

\subsection{Borehole volcanic stratigraphy}

Understanding the sub-surface geology of complex volcanic sequences is challenging due to the wide ranging physical properties of common volcanic facies, which very often overlap significantly (e.g. Bartetzko et al., 2005; Nelson et al., 2009). This complexity is expanded further in active volcanic systems and those which have undergone extensive sub-surface hydrothermal alteration, such as at Krafla, where geothermal exploration efforts attempt to identify and tap into feeder zones for high temperatures fluids. Alteration can have a major effect on the physical properties of different primary volcanic facies (Planke et al., 1999; Franzon et al., 2010; Marks et al., 2010). The distribution of fluid pathways and alteration are strongly affected by the distribution of volcanic facies (e.g. Thien et al., 2013), the presence of fractures and faults (Walker et al., 2013), along with the effects of hydrothermal venting associated with magma intrusion and pressure increase (e.g. Fournier, 1999; Ankasa et al., 2017) within volcanic systems. Within this study we have undertaken detailed analysis of ditch cuttings and wireline log data for the K-18 borehole incorporating new sonic log and televiewer analysis.

The application of a modified percentage based cuttings classification scheme has yielded promising results for wider application in volcanic geothermal settings, generally with good agreement between the results of the original cuttings analysis and the present study. The quantification and recording of altered cuttings that maintain limited to no vestiges of the original facies textures is an area which requires development in order to remove a priori interpretation. Even with the requirement for development in these scenarios, the non-genetic percentage based system of recording differing cuttings 
populations (e.g. Millett et al., 2014) is regarded as a potentially important step in improving inter-well correlation and repeatable cuttings mixing appraisal in volcanic geothermal settings, and can be integrated into conventional analysis at real-time drilling rates. Alongside the ditch cuttings study, the acquisition of sonic log data and BHTV data has been demonstrated to be of important utility for characterizing volcanic facies, facies boundaries, intrusions, and fracture zones. Volcanic facies interpretation from down borehole imaging logs is somewhat in its infancy, but where high resolution data is acquired detailed intra-facies variations can be clearly imaged from both BHTV and FMI imaging logs (Watton et al., 2014a), promoting an important role for high resolution acquisition in the future. Given the sonic log has, until now, rarely been deployed in geothermal boreholes on Iceland, this study lends strong support for its wider application.

From the basis of these integrated analyses, a geological interpretation of the K-18 borehole was enabled which forms a robust stratigraphic basis from which to appraise the zero offset VSP data collected from the K-18 borehole. The uppermost c. $380 \mathrm{~m}$ of the K-18 borehole is composed of a mixed sequence of hyaloclastites, scoria, volcaniclastic units and sparse lava flows which indicate the location underwent a number (up to four) of submergent to emergent cycles. The location was either covered by ice or a fluvio-lacustrine environment, periodically becoming sub-aerial either by volcanism breaking through the ice cover or the fluvio-lacustrine system being displaced. This complex facies sequence is underlain by a sequence of basaltic lavas and basaltic intrusions down to a depth of c. $800 \mathrm{~m}$. A clear change from basalt intrusions to much lower velocity mixed leucocratic tuffaceous to crystalline lithologies at c. $800 \mathrm{~m}$ depth is closely matched in both cuttings and wireline data. Primary textures are sparse due to pervasive alteration and replacement, however, based on gamma log data responses, at least two compositional units including a mafic dominated and more evolved sequence are present. In the lower part of this interval (logging Unit 4b), a number of high velocity basic intrusions (some could be lava flows) are inter-layered with the tuffaceous lithologies.

Beneath this tuffaceous sequence, mixed lava flows and intrusion dominated crystalline basalt dominates down to c. $1600 \mathrm{~m}$ at which depth a thin c. $80 \mathrm{~m}$ interval of highly altered cuttings is identified from which primary textures are not decipherable. The unit is thought to comprise a layer of completely altered densely compacted tuffaceous or hyaloclastite material, but could also potentially represent a completely altered fracture zone where leaching has destroyed any original crystalline or facies textures. Two prominent high gamma peaks below this unit are associated with low sonic velocities and are therefore provisionally interpreted as either thin tuffaceous layers or possibly highly fractured and altered felsic intrusions. Below this altered sequence from c. $1680 \mathrm{~m}$, crystalline basalt and dolerite to gabbroic intrusions are recorded uninterruptedly down to the bottom of the borehole at c. $2215 \mathrm{~m}$ supported by high NN and sonic Vp values. A clear increase in Vp, NN and resistivity data at c. 1880 $\mathrm{m}$ is inferred to represent the transition from minor sheet intrusions and lavas into larger more uniform 
A primary objective of the current study was to appraise the applicability of the VSP technique for imaging complex sub-surface volcanic geology in a high temperature geothermal field setting. It has been demonstrated in Figure 11 that key transitions and intervals of the subsurface geology within the K-18 borehole are clearly represented as changes in the zero offset VSP FB data. In Figure 12, the synthetic seismogram derived from the VSP P-wave corridor stack is presented and interpreted in terms of VSP reflectivity facies alongside the main borehole wireline and RTT intervals. The interpretation of the VSP reflectivity has focused on:

2. Major transitions between intervals with different reflectivity characteristics

\section{Isolated reflections}

By comparing the geological model, wireline data and relative amplitudes of the VSP corridor stack, reflections have been identified and rated in terms of relative prominence in Figure 12. A key observation is the fact that significant and coherent seismic energy is recorded throughout the borehole, even at c. $2.2 \mathrm{~km}$ depth, supporting previous studies findings that intrinsic attenuation is not a major problem for volcanic sequences (Pujol and Smithson, 1991). It is also clear, that a generally strong correspondence between the broad VSP facies and the borehole geological model exists, demonstrating that the VSP technique can image key aspects of the complex volcanic stratigraphy.

However, in a number of cases, clear boundaries from the geological borehole model (e.g. logging Unit 3 to $4 \mathrm{a}$ and $5 \mathrm{~g}$ to 6 transitions), appear relatively offset in the VSP reflectivity. It should be remembered that the corridor stack reflectivity is a summation of a $200 \mathrm{~ms}$ window corresponding to approximately c. 130 interval below the first break pick. In these cases, potential explanations could include the facies boundaries dipping or being very heterogeneous or uneven along the borehole path promoting scattering and ringing, and a subsequently low signal to noise ratio. Dipping and irregular volcanic facies boundaries are very commonly observed in various field analogues (e.g. Watton et al., 2013; Ebinghaus et al., 2014; Ankasa et al., 2017). Another possibility, especially given the highly intruded nature of the borehole, is that sub-vertical dike intrusions may be acting as wave-guides intersecting the borehole but also altering the velocity structure surrounding the borehole (e.g. Planke and Flóvenz, 1996). In the case of the basement transition in K-18 it is possible that the intrusive basement boundary from Unit $5 \mathrm{~g}$ to Unit 6 is highly irregular in three dimensions, and therefore might relate to an intrusion scenario where tongues of magma invade into the roof rock (e.g. Bédard et al., 
represent an apophysis of the basement intrusions, connected outside the borehole path causing significant scattering or focusing effects on the VSP derived seismic waves.

In general, this study has clearly demonstrated the potential utility of the VSP technique for imaging complex sub-surface volcanic geology in the high temperature geothermal field at Krafla. Due to a lack of a steam cap, super-critical domains or major feed zones in the K-18 borehole, the ability of the zero-offset VSP to image such features could not be tested within this study. In scenarios where these features are present (e.g. in other boreholes and regions within the Krafla geothermal field), the utility of VSP techniques (especially far-offset and look ahead applications) to characterize and / or potentially be deployed for time-lapse monitoring (e.g. Khatiwada et al., 2012), remains to be tested. With the data acquired during the IMAGE project, additional techniques such as coda wave interferometry or attenuation tomography could potentially be applied in the future in order to further assess the utility of the VSP data for field characterization in volcanic settings (Khatiwada et al., 2012; De Siena et al., 2014).

\section{Conclusions}

Within this study, we have presented a comprehensive appraisal of the volcanic facies and stratigraphy within the K-18 borehole from the Krafla high temperature geothermal field on Iceland. We have developed and tested analytical approaches for the interpretation of volcanic ditch cuttings in geothermal boreholes, highlighting the potential of a percentage based classification approach along with presenting to our knowledge the first published borehole sonic log data for a high temperature geothermal field on Iceland. The sonic log velocity data has been demonstrated to improve the interpretation of volcanic facies in the K-18 borehole, especially for intruded and tuffaceous intervals, strongly supporting its wider deployment for geothermal boreholes in volcanic settings. Integration of processed zero-offset VSP data for K-18, with the borehole geological model has been undertaken to appraise the applicability of the VSP technique for imaging sub-surface geology in high temperature volcanic geothermal fields. The results of the integrated analysis clearly support the ability of the VSP technique to characterize complex volcanic geology in the sub-surface, including key stratigraphic boundaries and intrusions, along with giving important insights into the internal reflectivity characteristics of different volcanic facies intervals. Some offsets in the depth of transitions are encountered between the borehole geology and the VSP reflectivity. These offsets are interpreted to result from complex and dipping intrusion geometries acting as wave guides, along with potentially irregular facies boundaries outside of the well path, all comprising features commonly observed in field analogues. No major fluid injection zones, super-critical domains or steam caps are known from the K18 borehole, and thus the imaging of such zones could not be accomplished by the zero-offset VSP in this study. However, given that these features are known to be present within the wider Krafla 
geothermal field, our findings provide a base line for appraising the results of far offset and look-ahead VSP imaging of such features at the Krafla site. Imaging of these zones along with regions with molten magma, also known to exist at Krafla, form key goals for wider geothermal exploration, especially in the pre-drilling or shallow test borehole stage.

\section{Acknowledgements}

The research leading to these results has received funding from the European Community's Seventh Framework Programme under grant agreement No. 608553 (Project IMAGE). The VMAPP project run by VBPR, DougalEARTH Ltd.and TGS also contributed funding to the borehole characterization of the K-18 borehole. Landsvirkun is acknowledged for their effort and assistance in this work and in particular for allowing the use of the data from well K-18. We further acknowledge the support from the Research Council of Norway through its Centres of Excellence funding scheme, project 22372 (SP and DAJ).

\section{Figure captions}

Figure 1. Summary bedrock geological map of Iceland showing the location of the Krafla high temperature geothermal area (Hjartarson and Samundsson, 2014).

Figure 2. Krafla Geothermal field and location of production wells. Well tracks and roads are shown with green and brown respectively and the K-18 study borehole is indicated with a blue oval. Selected surface geological features including faults (ticked black lines) and crater rows/spatter/scoria (red lines and circles) are also shown.

Figure 3. a. Schematic diagram highlighting some of the main features that may affect ditch cuttings quality and representativeness (modified after Brister and McIntosh, 2004). b. Conceptual diagram highlighting the effect that annulus mixing may have on retrieved cuttings assemblage percentages for the same collection interval.

Figure 4. a. Volcanic ditch cuttings ternary classification, after Millett et al. (2014). b. Example of expected response through an intruded hyaloclastite sequence from southern Iceland. $c$. Example of the detailed percentage based output for the K-18 borehole (this study) plotted next to the original borehole cuttings interpretation (Guðmundsson et al., 1981).

Figure 5. a. Sonic log $P$-wave velocity $(\mathrm{km} / \mathrm{s})$ versus neutron API for all $K-18$ data. The best trendline fit is derived from a log function regression. Separate fields within the data array are broadly linked to different facies groups but large overlap is also present. $b$. Manually fitted composite linear 
function for the data which better represents the different facies variations on the low and high Vp/API ranges.

Figure 6. Processed VSP P-wave data for K-18. a. Full stack. b. Corridor stack comprising a summation over a corridor of $200 \mathrm{~ms}$ below first breaks (dashed line) to exclude multiple reflections. c. NMO P-wave section. The corridor stack emphasizes the loss of reflectivity below $850 \mathrm{~m}$, corresponding to 700-1200 ms two-way time (TWT). See Planke et al. (2016) and Vakulenko and Buryak (2016) for further details.

Figure 7. Summary of the K-18 cuttings analysis groupings and interpretation packages derived from cuttings data alone. The original cuttings analysis incorporating the interpretation scheme commonly utilized on Iceland (key as in Figure 4) is also presented for comparison along with alteration zones (modified after Guðmundsson et al., 1981). Major intervals from the current Petrel model for the Krafla geothermal field are also presented.

Figure 8. Key cuttings examples from the K-18 borehole. a. Highly vesicular individual cuttings of glass and crystalline basalt, showing variable alteration from fresh to near complete replacement. b. Volcaniclastic silt to fine grained sandstone. c. Highly vesicular to pumice like intricate pyroclasts in blocky cemented tuffaceous cuttings. d. Tachylitic fresh glass shards in altered dull lustre palagonite/clay matrix. e. Highly vesicular scoriaceous crystalline cuttings with early onset of clay precipitation at vesicle rims. $f$. Remnant pumice texture in highly altered and recrystallized assemblage. g. Very pale leucocratic mixed crystalline to altered tuffaceous cuttings. h. Cuttings assemblage with fresh basalt cuttings mixed within a leucocratic dominated section.

Figure 9. Composite wireline logs for the K-18 borehole along with the broad wireline units compared to the cuttings log. Feed points (blue arrows) along with the borehole dimensions are also annotated.

Figure 10. Summary of BHTV structural analyses for the K-18 borehole, modified after Árnadóttir (2014) and Blischke et al. (2016). The structural log shows two classes of interpretation certainty, where CL1 indicates a higher certainty compared to CL2.

Figure 11. VSP P-wave velocity Reduced Travel Time (RTT) along with interval Vp, Vs, Vp/Vs and sonic Vp plotted against depth for the K-18 borehole. Interval averages including neutron derived $V p$ data are indicated by a dashed line. Arrows display the main RTT gradient breaks and intervals with similar average velocities are interpreted based on the RTT versus depth gradient and labelled L1-L10. Borehole logging units and the VSP P-wave outer corridor stack are shown for reference.

Figure 12. VSP seismogram reflectivity character and facies assessment compared to the borehole wireline and geological model. 
Table 1. Summary of K-18 borehole data available for this study. Abbreviations: OS (Orkustofnun / National Energy Authority) and LV (Landsvirkjun / National Power Company of Iceland).

Table 2. Summary of the reduced travel time RTT VSP Vp interval velocities for K-18 borehole compared to sonic log velocity $\left(V p_{L}\right)$. *Log velocities for intervals L2-L4 include estimated values derived from neutron log data (NN) as outlined in the methods section.

\section{References}

Abdelmalak, M.M., Planke, S., Faleide, J.I., Jerram, D.A., Zastrozhnov, D., Eide, S., Myklebust, R., 2016. The development of volcanic sequences at rifted margins: new insights from the structure and morphology of the Vøring Escarpment, mid-Norwegian Margin. Journal of Geophysical Research: Solid Earth, 2015JB012788.

Angkasa, S.S., Jerram, D.A., Millett, J.M., Svensen, H.H., Planke, S., Taylor, R.A., Schofield, N., Howell, J., 2017. Mafic intrusions, hydrothermal venting, and the basalt-sediment transition: Linking onshore and offshore examples from the North Atlantic igneous province. Interpretation, 5(3), SK83-SK101, https://doi.org/10.1190/INT-2016-0162.1

Ármannsson, H., Guðmundsson, Á., Steingrímsson, B.S., 1987. Exploration and development of the Krafla geothermal area. Jökull, 37, 13-30.

Árnadóttir, S., 2014. Results of Televiewer Logging in Well K-18 in Krafla High Temperature Area, NE-Iceland. IMAGE report - D4.2, available online at http://www.image-fp7.eu. ÍSOR report - 2014/066, 21 pp + appendix.

Árnason, K., Vilhjálmsson, A.M., Björnsdóttir, P., 2008. A study of the Krafla volcano using gravity, micro-earthquake and MT data. In: Interim ÍSOR Report to Landsvirkjun (unpublished).

Bartetzko, A., Delius, H., Pechnig, R., 2005. Effect of compositional and structural variations on log responses of igneous and metamorphic rocks. I: mafic rocks. Geological Society, London, Special Publications, 240(1), 255-278.

Bédard, J.H., Naslund, H.R., Nabelek, P., Winpenny, A., Hryciuk, M., Macdonald, W., Hayes, B., Steigerwaldt, K., Hadlari, T., Rainbird, R., Dewing, K., 2012. Fault-mediated melt ascent in a Neoproterozoic continental flood basalt province, the Franklin sills, Victoria Island, Canada. Geological Society of America Bulletin, 124(5-6), 723-736.

Blischke, A., Árnadóttir, S., Helgadóttir, H.M., Millett, J.M., 2016. Well K-18 in the Krafla High temperature Field, NE-Iceland: Review of Wireline and Televiewer Log Data, and Electronic 
Facies Log (EFL) Preliminaries. IMAGE report - D4.2, available online at http://www.imagefp7.eu. ÍSOR report - 2016/021, 84 pp + appendix.

Brister, B.S., McIntosh, W.C., 2004. Identification and correlation of Oligocene ignimbrites in well bores, Alamosa Basin (northern San Luis Basin), Colorado, by single crystal laser fusion 40Ar/39Ar geochronology of well cuttings. New Mexico Bureau of Geology and Mineral Resources, Bulletin, 160, 281-296.

Broglia, C., Ellis, D., 1990. Effect of Alteration, Formation Absorption, and Standoff on the Response of the Thermal Neutron Porosity Log in Gabbros and Basalts: Examples From Deep Sea Drilling Project-Ocean Drilling Program Sites. Journal of Geophysical Research, 95(B6), 91719188.

Christie, P., Gollifer, I., Cowper, D., 2006. Borehole seismic studies of a volcanic succession from the Lopra-1/1A borehole in the Faroe Islands, northern North Atlantic. Geological Survey of Denmark and Greenland Bulletin, 9, 23-40.

De Siena, L., Thomas, C., Waite, G.P., Moran, S.C., Klemme, S., 2014. Attenuation and scattering tomography of the deep plumbing system of Mount St. Helens. Journal of Geophysical Research: Solid Earth, 119(11), 8223-8238.

Delpino, D.H., Bermúdez, A.M., 2009. Petroleum systems including unconventional reservoirs in intrusive igneous rocks (sills and laccoliths). The Leading Edge, 28(7), 804-811. DOI: $10.1190 / 1.3167782$

Ebinghaus, A., Hartley, A.J., Jolley, D.W., Hole, M., Millett, J., 2014. Lava-sediment interaction and drainage-system development in a large igneous province: Columbia River Flood Basalt Province, Washington State, USA. Journal of Sedimentary Research, 84(11), 1041-1063.

Einarsson, P., 1978. S-wave shadows in the Krafla caldera in NE-Iceland, evidence for a magma chamber in the crust. Bulletin of Volcanology, 41, 1-9.

Elders, W.A., Friðleifsson, G.Ó., Albertsson, A., 2014. Drilling into magma and the implications of the Iceland Deep Drilling Project (IDDP) for high-temperature geothermal systems worldwide. Geothermics, 49, 111-118.

Flóvenz, Ó.G., Steingrímsson, B.S., 2009. The geothermal resources of Iceland. Geothermal Resources Council Transactions, 33, 383-387.

Fournier, R.O., 1999. Hydrothermal processes related to movement of fluid from plastic into brittle rock in the magmatic-epithermal environment. Economic Geology, 94(8), 1193-1211. 
Franzson, H., Guðfinnsson, G.H., Helgadóttir, H.M., Frolova, J., 2010. Porosity, density and chemical composition relationships in altered Icelandic hyaloclastites. Birkle and Torres-Alvarado (ed), Water-Rock Interaction. London: Taylor and Francis Group, 199-202.

Franzson, H., Gudlaugsson, S., Fridleifsson, G., 2001, May. Petrophysical properties of Icelandic rocks. In Proceedings of the 6th Nordic Symposium on Petrophysics. Trondheim, Norway.

Fridleifsson, G.Ó., Ármannsson, H., Mortensen, A., 2006. Geothermal conditions in the Krafla caldera with focus on well KG-26. Iceland GeoSurvey, report, ÍSOR-2006/030.

Friðleifsson, G.Ó., Elders, W. A., Bignall, G., Nielson, D., 2013. A plan for a 5 km-deep borehole at Reykjanes, Iceland, into the root zone of a black smoker on land. Scientific Drilling, 16, 7379. DOI:10.5194/sd-16-73-2013

Fridleifsson, G.Ó., Elders, W.A., 2005. The Iceland Deep Drilling Project: a search for deep unconventional geothermal resources. Geothermics, 34(3), 269-285.

Fridleifsson, I.B., 2001. Geothermal energy for the benefit of the people. Renewable and sustainable energy reviews, 5(3), 299-312.

Guðmundsson, Á., 2005. Geothermal Data Collection and Consultancy at Drill Site. Proceedings World Geothermal Congress. Antalya, Turkey, 1-6.

Guðmundsson, Á., Steingrímsson, B., Halldórsson, G. K., Guðmundsson, G., Stefánsson, V., 1981. Krafla hola KJ-18: Borun vinnsluhluta og borlok. Orkustofnun, report, ÁG-BS-GKH-GHGVS-81/05. (In Icelandic.)

Halldórsdóttir, S., Erlendsson, Ö., Hersir, G.P., Gunnarsson, K., Blischke, A., Helgadóttir, H.M., Árnadóttir, Á., Blanck, H., 2014. Vertical Seismic Profiling (VSP) Experiment in Krafla, NEIceland. Field Report - Summary of Operations from May to June 2014. IMAGE report D4.2, available online at http://www.image-fp7.eu. ÍSOR report - 2014/073, 74 pp + appendices on $\mathrm{CD}$.

Helm-Clark, C.M., Rodgers, D.W., Smith, R.P., 2004. Borehole geophysical techniques to define stratigraphy, alteration and aquifers in basalt. Journal of applied geophysics, 55(1), 3-38.

Hersir, G.P., Erlendsson, Ö., Ingólfsson, H., Stefánsson, H.Ö., and Trygggvason, H., 2016. Sonic Logging - A Field Report for Well K-18 in Krafla, NE-Iceland, and Well YT-2 and LA-8 in Eyjafjörður, N-Iceland. IMAGE report - D4.2, available online at http://www.image-fp7.eu. ÍSOR report - 2016/028, 22 pp.

Hjartarson, Á., Sæmundsson, K., 2014. Geological Map of Iceland. Bedrock. 1:600.000. Reykjavík, Iceland GeoSurvey. 
Iyer, K., Schmid, D.W., Planke, S., Millett, J., 2017. Modelling hydrothermal venting in volcanic sedimentary basins: Impact on hydrocarbon maturation and paleoclimate. Earth and Planetary Science Letters, 467, 30-42.

Jerram, D.A., Single, R.T., Hobbs, R.W., Nelson, C.E., 2009. Understanding the offshore flood basalt sequence using onshore volcanic facies analogues: an example from the Faroe-Shetland basin. Geological Magazine 146, 353-367.

Khatiwada, M., Adam, L., Morrison, M., van Wijk, K., 2012. A feasibility study of time-lapse seismic monitoring of CO 2 sequestration in a layered basalt reservoir. Journal of Applied Geophysics, 82, 145-152.

Lund, J.W., Freeston, D.H., Boyd, T.L., 2005. Direct application of geothermal energy: 2005 worldwide review. Geothermics, 34(6), 691-727.

Marks, N., Schiffman, P., Zierenberg, R.A., Franzson, H., Fridleifsson, G.Ó., 2010. Hydrothermal alteration in the Reykjanes geothermal system: Insights from Iceland deep drilling program well RN-17. Journal of Volcanology and Geothermal Research, 189(1), 172-190.

Millett, J.M., Hole, M.J., Jolley, D.W., 2014. A fresh approach to ditch cutting analysis as an aid to exploration in areas affected by large igneous province (LIP) volcanism. Geological Society, London, Special Publications, 397(1), 193-207.

Millett, J.M., Hole, M.J., Jolley, D.W., Schofield, N., Campbell, E., 2015. Frontier exploration and the North Atlantic Igneous Province: new insights from a $2.6 \mathrm{~km}$ offshore volcanic sequence in the NE Faroe-Shetland Basin. Journal of the Geological Society, 173(2), 320-336.

Millett, J.M., Paris, J.C., Helgadóttir, H.M., Planke, S., Blischke, A., Jerram, D.A., 2016a. Wireline Logging and Cutting Analysis in Well K-18, Krafla High-Temperature Area, NE-Iceland. IMAGE-D4.8, available online at: http://www.image-fp7.eu. Appendix A.4, 86 pp.

Millett, J.M., Wilkins, A.D., Campbell, E., Hole, M.J., Taylor, R.A., Healy, D., Jerram, D.A., Jolley, D.W., Planke, S., Archer, S.G., Blischke, A., 2016a. The geology of offshore drilling through basalt sequences: Understanding operational complications to improve efficiency. Marine and Petroleum Geology, 77, 1177-1192.

Mortensen, A.K., Egilson, P., Gautason, B., Árnadóttir, S., Guðmundsson, Á., 2014. Stratigraphy, alteration mineralogy, permeability and temperature conditions of well IDDP-1, Krafla, NEIceland. Geothermics, 49, 31-41.

Muirhead, J.D., Airoldi, G., White, J.D., Rowland, J.V., 2014. Cracking the lid: Sill-fed dikes are the likely feeders of flood basalt eruptions. Earth and Planetary Science Letters, 406, 187-197. 
Nelson, C., Jerram, D., Hobbs, R. 2009. Flood basalt facies from borehole data: implications for prospectivity and volcanology in volcanic rifted margins. Petroleum Geoscience, 15, 313-324.

Nielsen, G., Maack, R., Gudmundsson, Á., Gunnarsson, G. I., 2000. Completion of Krafla geothermal power plant. Proceedings World Geothermal Congress, Kyushu-Tohoku, Japan, 28, 32593264.

Petersen, U.K., Andersen, M.S., Brown, R.J., 2015. Geophysical aspects of basalt geology and identification of intrabasaltic horizons. In Faroe Islands Exploration Conference: Proceedings of the 4th Conference. Annales Societatis Scientiarum Færoensis, Tórshavn, Faroe Islands, Supplementum, 64, 76-93.

Planke, S. (editor), Halldórsdóttir, S., Hersir, G.P., Erlendsson, Ö., Gunnarsson, K., Flóvenz, Ó.G., Millett, J.M., Giese, R., Kästner, F., Oye, V., Vakulenko, S., Júlíusson, E., 2016. IMAGED4.2. Summary Report of WP 4.2: Active Seismic with VSP. IMAGE report - D4.2, available online at http://www.image-fp7.eu. ÍSOR report - 2016/049, 75 pp + appendices on CD.

Planke, S., 1994. Geophysical response of flood basalts from analysis of wire line logs: Ocean Drilling Program Site 642, Vøring volcanic margin. Journal of Geophysical Research, 99(B5), 9279-9296.

Planke, S., Cambray, H., 1998. Seismic properties of flood basalts on rifted volcanic margins based on Ocean Drilling Program (ODP) Hole 917A downhole data. Proceedings of the Ocean Drilling Program, Scientific Results, 152, 453-462.

Planke, S., Cerney, B., Nilsen, O., 1999. Alteration effects on petrophysical properties of subaerial flood basalts: Site 990, Southeast Greenland Margin, Proceedings of the Ocean Drilling Program, Scientific Results, 163, 17-28.

Planke, S., Eldholm, O., 1994. Seismic response and construction of seaward dipping wedges of flood basalts: Vøring volcanic margin. Journal of Geophysical Research: Solid Earth, 99(B5), 92639278.

Planke, S., Flóvenz, Ó.G., 1996. Seismic properties of flood basalts. Norwegian Petroleum Society Conference on Seismic Lithology. Kristiansand, March 11-13.

Planke, S., Symonds, P.A., Alvestad, E., Skogseid, J., 2000. Seismic volcanostratigraphy of largevolume basaltic extrusive complexes on rifted margins. Journal of Geophysical Research, 105(B8), 19335-19351.

Pujol, J., Smithson, S., 1991. Seismic wave attenuation in volcanic rocks from VSP experiments. Geophysics, 56(9), 1441-1455. 
Sæmundsson, K., 1991. Jardfræði Kröflukerfisins (The geology of the Krafla system). In Náttúra Mývatns, ed. Arnpór Garðarsson and Árni Einarsson. HÍN, 24-95.

Santilano, A., Manzella, G., Gianelli, G., Donato, A., Gola, G., Nardini, I., Trumpy, E., and Botteghi, S., 2015. Convective, intrusive geothermal plays: what about tectonics? Geothermal Energy Science, 3, 51-59.

Scott, S., Driesner, T., Weis, P., 2015. Geologic controls on supercritical geothermal resources above magmatic intrusions. Nature communications, 6. DOI: 10.1038/ncomms8837

Shaw, F., Worthington, M.H., White, R.S., Andersen, M.S., Petersen, U.K., 2008. Seismic attenuation in Faroe Islands basalts. Geophysical Prospecting, 56(1), 5-20.

Stefánsson, V., Gudlaugsson, S.T., Guðmundsson, Á., 2000. Silica content and gamma ray logs in volcanic rocks. Proceedings of the World Geothermal Congress, Kyushu-Tohoku, Japan, 28, 2893-2897.

Thien, B.M., Kosakowski, G., Kulik, D.A., 2015. Differential alteration of basaltic lava flows and hyaloclastites in Icelandic hydrothermal systems. Geothermal Energy, 3(11). DOI 10.1186/s40517-015-0031-7

Tuffen, H., Castro, J.M., 2009. The emplacement of an obsidian dike through thin ice: Hrafntinnuhryggur, Krafla Iceland. Journal of Volcanology and Geothermal Research, 185(4), $352-366$

Vakulenko, S., Buryak, S., 2016. Seismic VSP experiment in Krafla: processing report. IMAGE report - D4.8, available online at http://www.image-fp7.eu. Appendix A.2, 51 pp.

Vanorio, T., De Matteis, R., Zollo, A., Batini, F., Fiordelisi, A., Ciulli, B., 2004. The Deep Structure of the Larderello-Travale geothermal field from 3D microearthquake traveltime tomography. Journal of Geophysical Research, 31, L07613.

Vilhjálmsson, A.M., Hersir, G.P., Flóvenz, Ó. G., 2016. Resistivity vs Temperature during Heating up of Well KJ-18 in Krafla, NE-Iceland. IMAGE report - D3.3, available online at http://www.image-fp7.eu. ÍSOR report - 2016/045, 22 pp.

Walker, R.J., Holdsworth, R.E., Imber, J., Faulkner, D.R., Armitage, P.J., 2013. Fault zone architecture and fluid flow in interlayered basaltic volcaniclastic-crystalline sequences. Journal of Structural Geology, 51, 92-104.

Watton, T.J., Cannon, S., Brown, R.J., Jerram, D.A., Waichel, B.L., 2014a. Using formation microimaging, wireline logs and onshore analogues to distinguish volcanic lithofacies in boreholes: examples from Palaeogene successions in the Faroe-Shetland Basin, NE Atlantic. Geological Society, London, Special Publications, 397(1), 173-192. 
Watton, T.J., Jerram, D.A., Thordarson, T., Davies, R.J., 2013. Three-dimensional lithofacies variations in hyaloclastite deposits. Journal of Volcanology and Geothermal Research, 250, 19-33.

Watton, T.J., Wright, K.A., Jerram, D.A., Brown, R.J., 2014b. The petrophysical and petrographical properties of hyaloclastite deposits: Implications for petroleum exploration. Am. Assoc. Pet. Geol. Bull. 98, 449-463. doi:10.1306/08141313029

Weisenberger, T.B., Arnaldsson, A., Blischke, A., Óskarsson, F., Axelsson, G., Berthet, J.C.C., Ármannsson, H., Blanck, H., Helgadóttir, H.M., Árnason, K., Ágústsson, K., Gylfadóttir, S.S., Guðmundsdóttir, V., 2015. Revision of the Conceptual Model of the Krafla Geothermal System. Íslenskar orkurannsóknir, ÍSOR-2015/012, LV-2015-040.

Weisenberger, T.B., Ingimarsson, H., Hersir G.P., Flóvenz, Ó.G., 2016. IMAGE Task 3.3 - Physical Properties of Rock at Reservoir Conditions. Validation of the Influence of Cation-exchange Capacity (CEC) on Resistivity Logs within Hydrothermal Systems IMAGE report - D3.3, available online at http://www.image-fp7.eu. ÍSOR report - 2016/044, 41 pp.

White, R.S., Smallwood, J.R., Fliedner, M.M., Boslaugh, B., Maresh, J., Fruehn, J., 2003. Imaging and regional distribution of basalt flows in the Faeroe-Shetland Basin. Geophysical Prospecting, 51(3), 215-231.

Ziegler, M., Heidbach, O., Rajabi, M., Hersir, G.P., Ágústsson, K., Árnadóttir, S., Zang, A., 2016. The stress pattern of Iceland. Tectonophysics, 674, 101-113.

Zoback, M.D., Moos, D., Mastin, L., Anderson, R.N., 1985. Well bore breakouts and in situ stress. Journal of Geophysical Research: Solid Earth, 90(B7), 5523-5530. 


\section{ís口R}

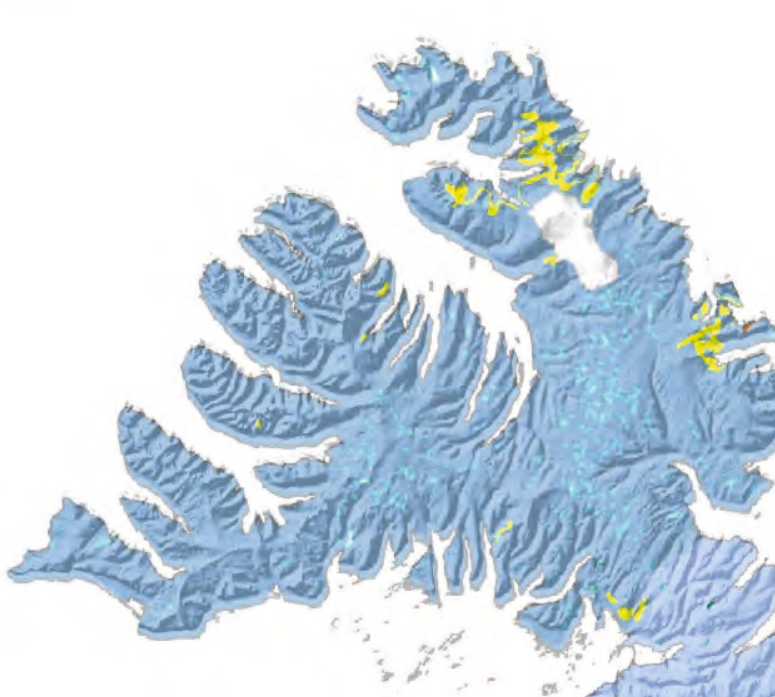<smiles>[C]1C[Al]1</smiles>

Tertiary bedrock

Early Pleistocene bedrock

Late Pleistocene lavas

Late Pleistocene hyaloclastites

Rhyolite

Intrusive rocks

1 Postglacial lavas

Alluvium deposits

Ice cover

$\approx$ Volcanic zone

$\check{8}$

$\begin{array}{lll}0 & 50 & 100 \mathrm{~km}\end{array}$

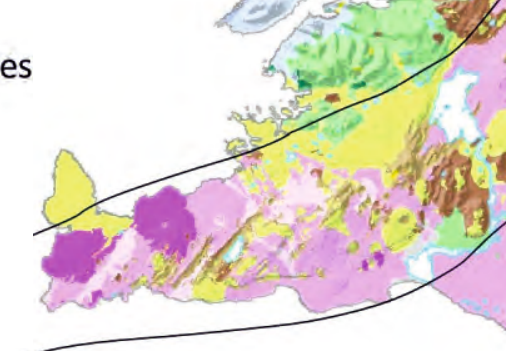

\section{Reykjanes \\ Peninsula}

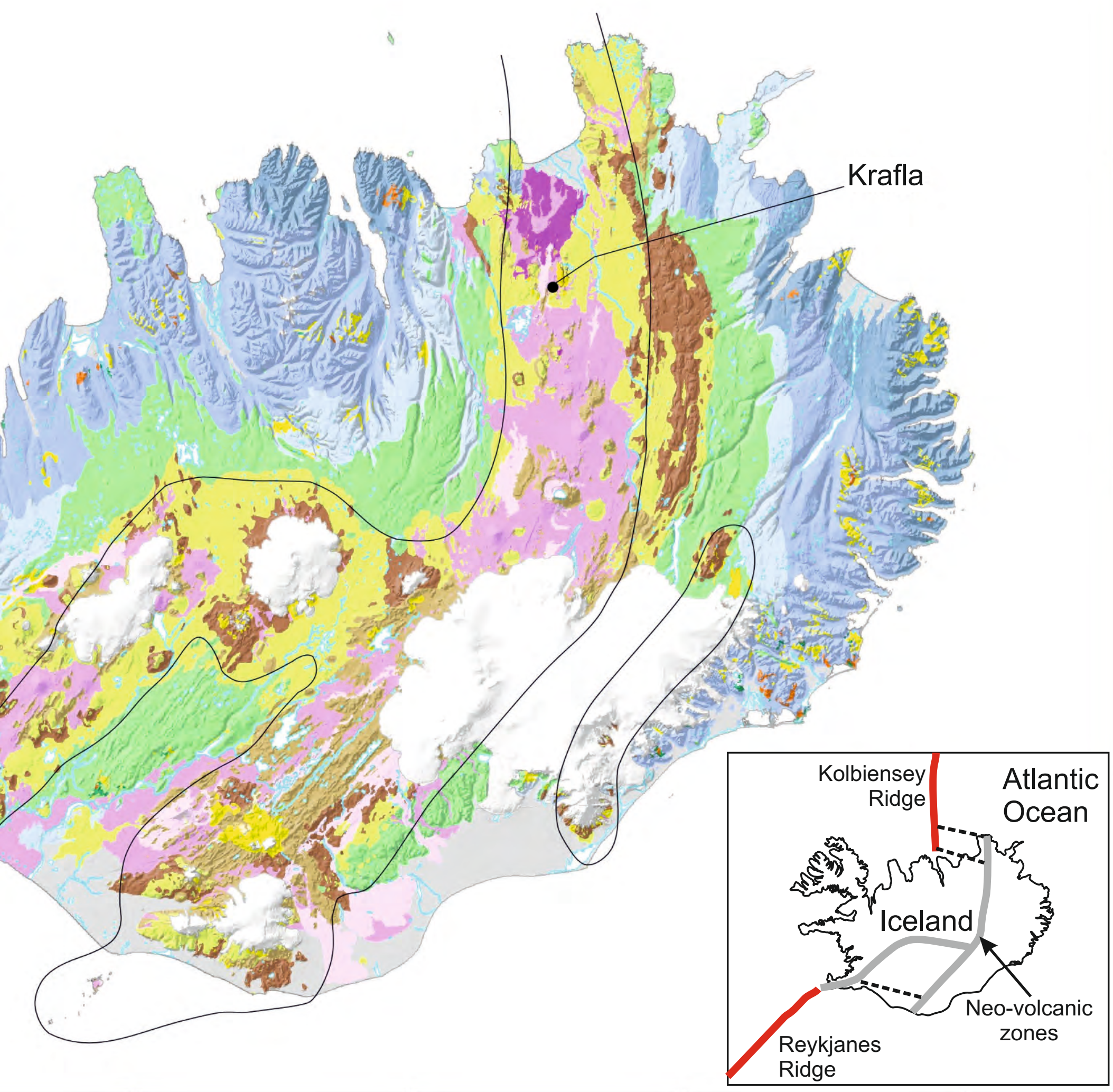



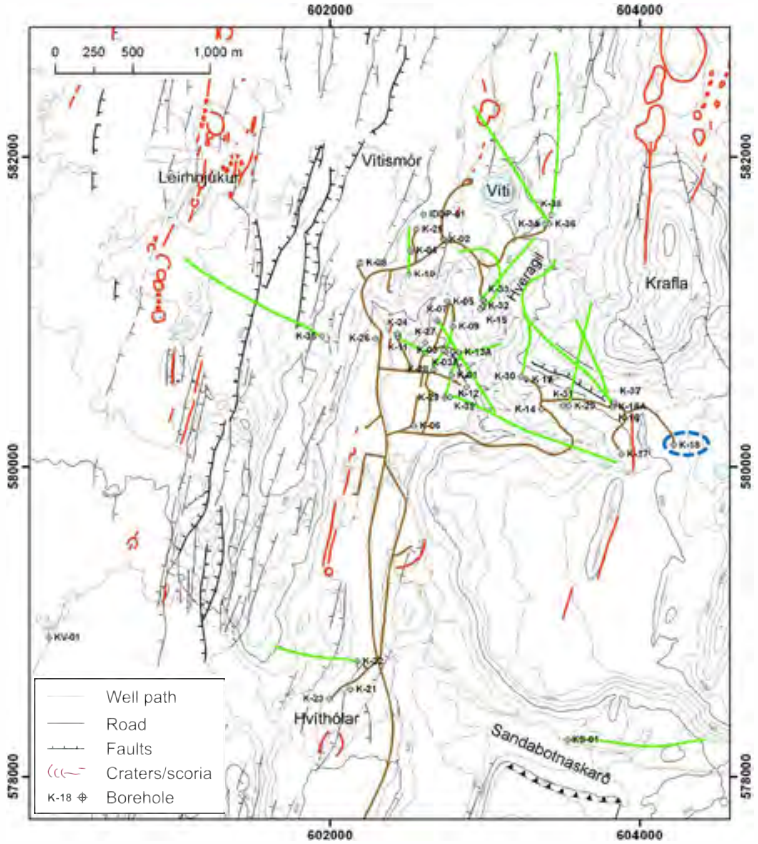
a.

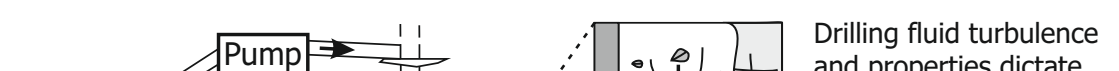

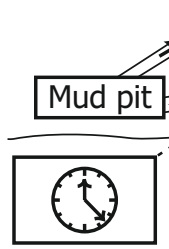

Cuttings quality and resolution is only ever as good as the collection care and timing
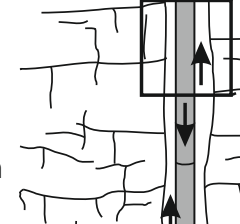

[...

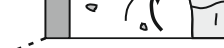$$
\text { care and timing }
$$
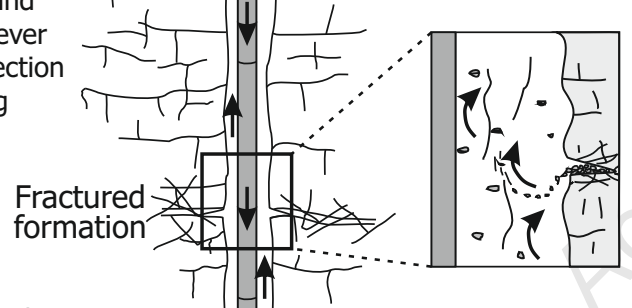

r

Initial cuttings quality is dependent on the drill bit and drilling conditions

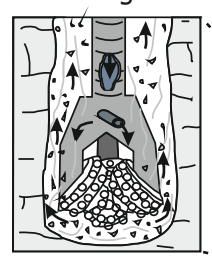

$-$

Soft

$-\frac{1}{1}$

$\frac{t}{1}$

Soft

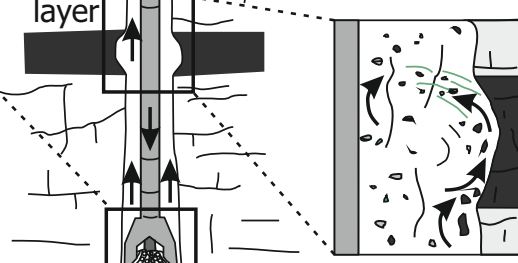

and properties dictate

the effectiveness of

cutting transport

In certain cases denser cuttings may lag behind less dense cuttings e.g. coal

Bore-hole roughness and cavities may collect cuttings and release them out of sequence

Weak formation may be preferentially eroded or 'washed-out' causing contamination and possible erroneous designation

Soft cuttings may be abraded and rounded causing poor preservation and poor representation b.

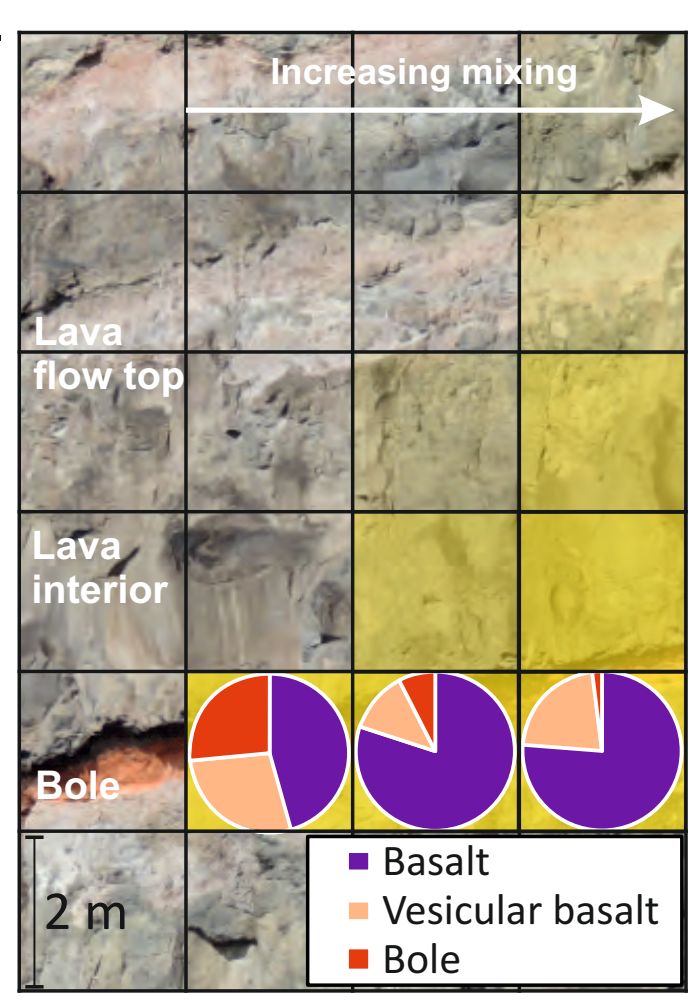



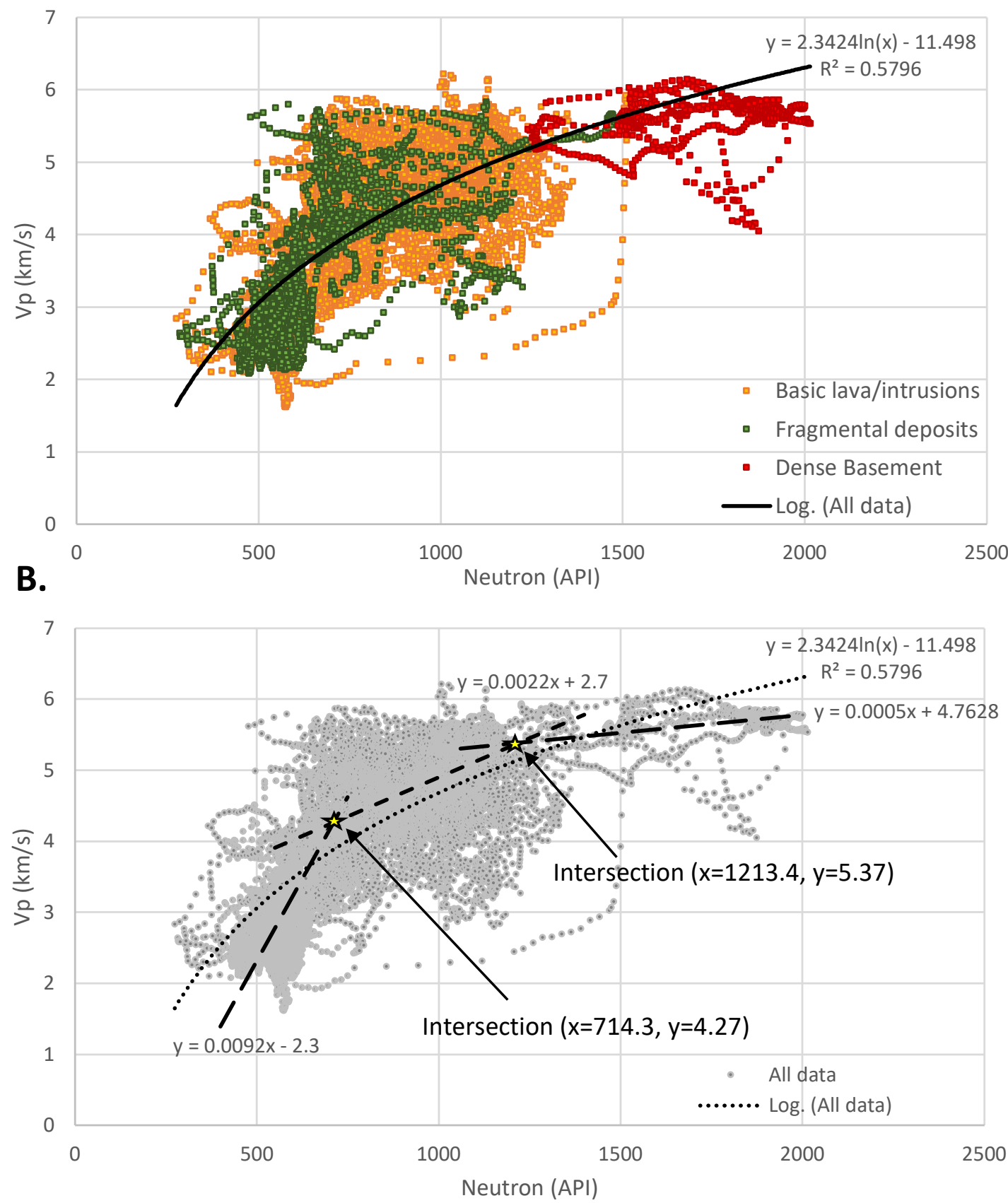


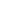




\section{Depth Caliper}

(m) (mm) Crystalline Glass Epiclastic Alt. Ternary

Cuttings Original Krafla Petrel Geological

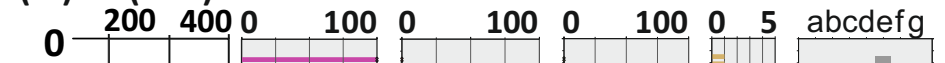
groups cuttings analyses model interpretation groups

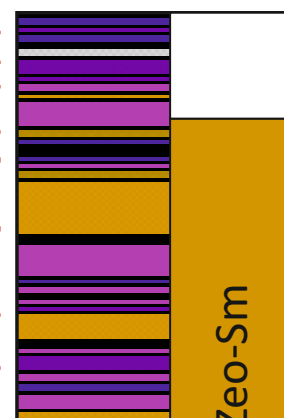

Hraun 0 (B)
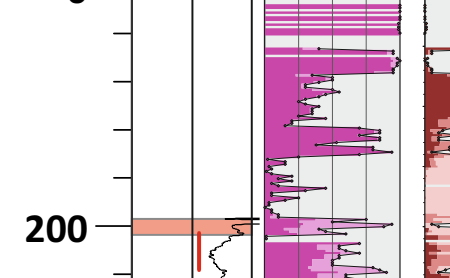

400
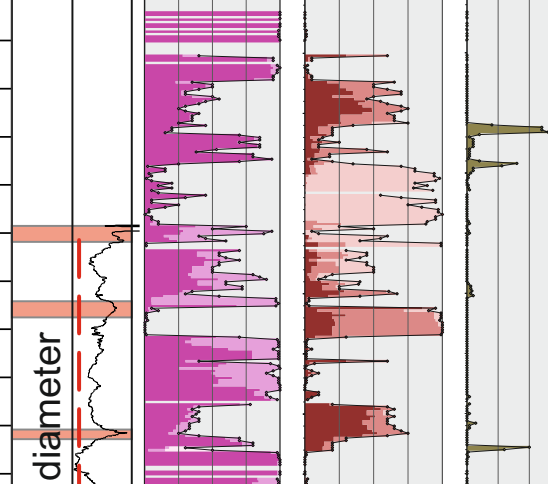

\section{0}
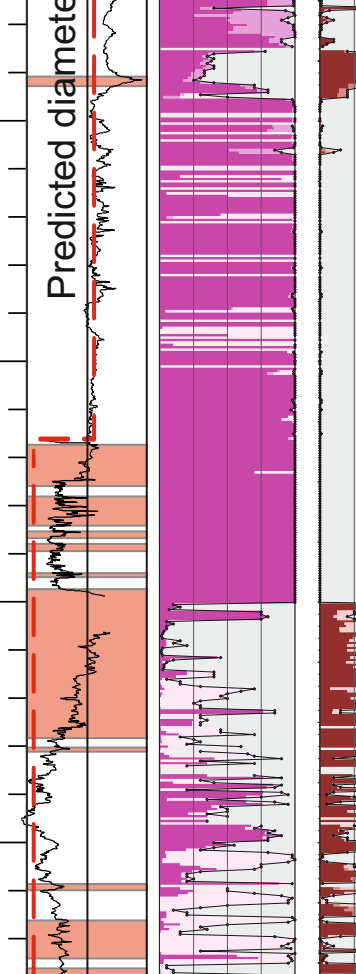

100
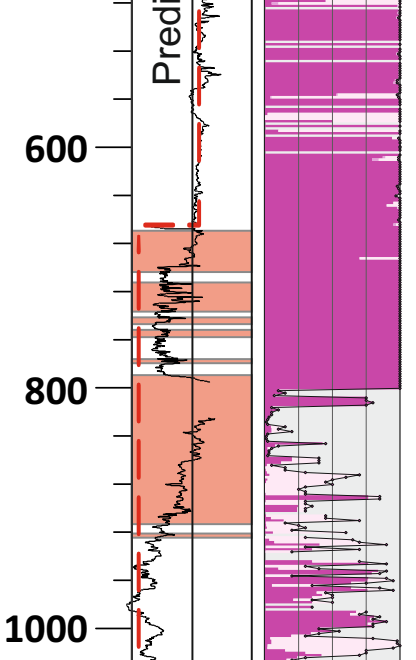

1200
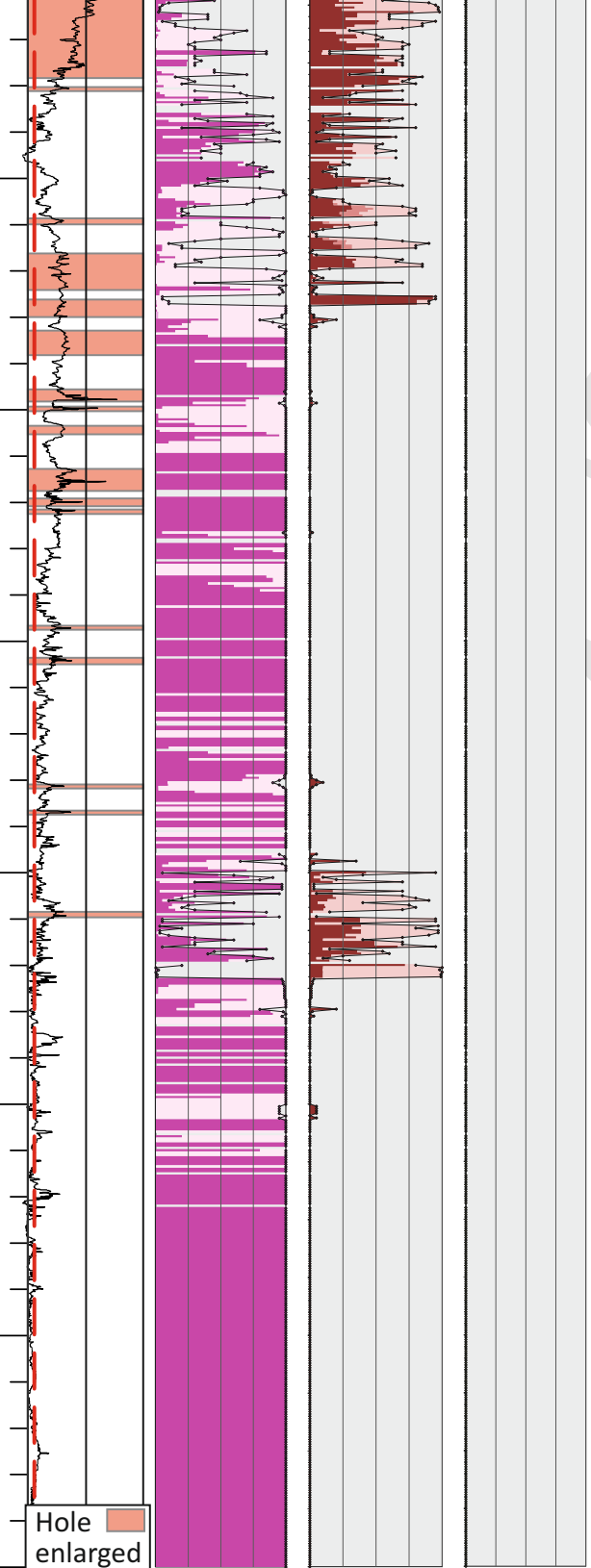

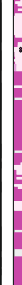

140

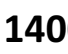

$\frac{5}{5}$
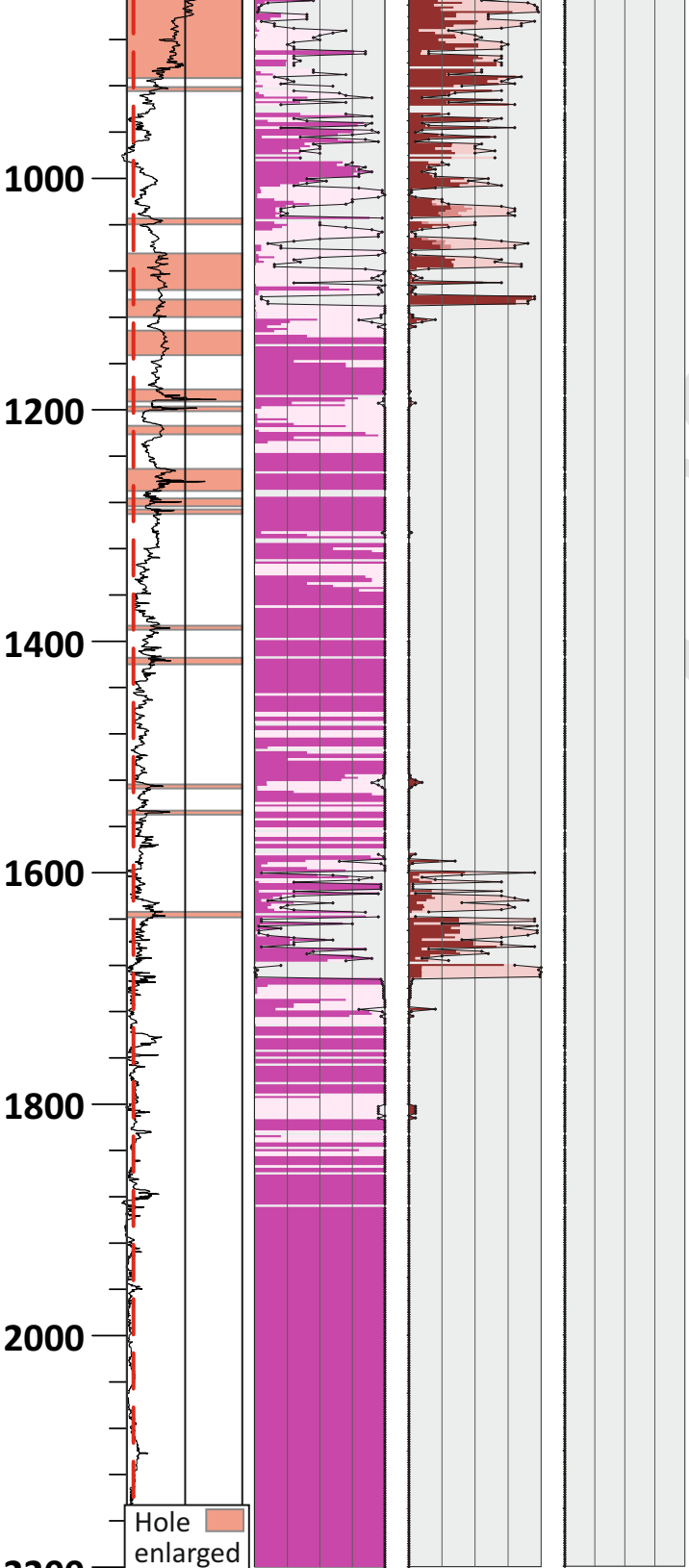

\section{Cuttings Groups}

Group 1 - Mafic fine to medium crystalline dominated

Group 2 - Highly vesicular / scoriacous crystalline basalt

Group 3 - Thin boundaries (flow tops, ash layers or reworking)

Group 4 - Sedimentary volcaniclastic Hraun: lavas

Group 5 - Glass / tuff dominated sequences

Group 6 - Evolved crystalline unit

Moberg: pillow/

hyaloclastite/ tuff

Group 7 - Mixed leucocratic crystalline / pseudomorphs after glass Group 8 - Mafic medium to coarse crystalline basement 


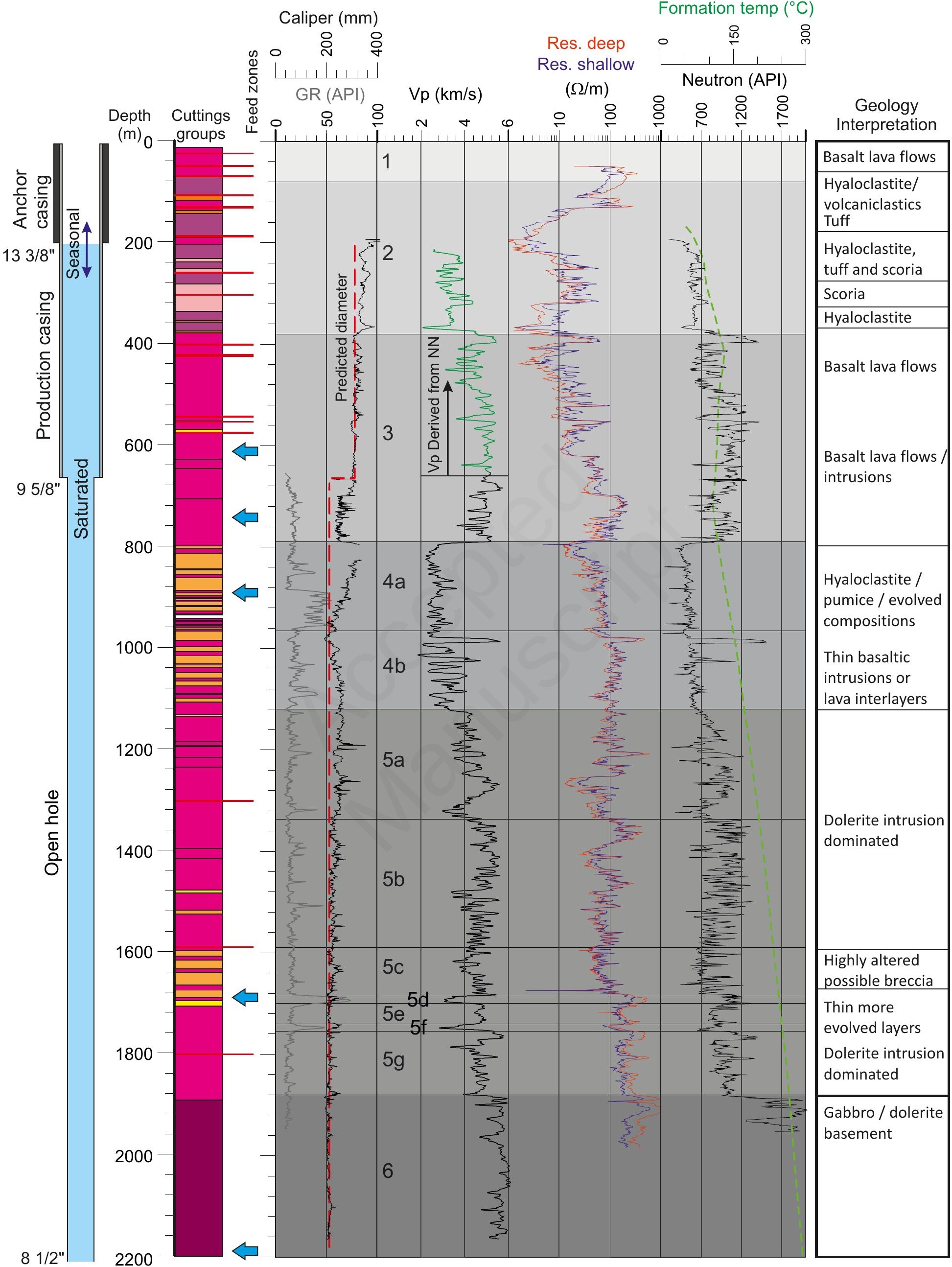




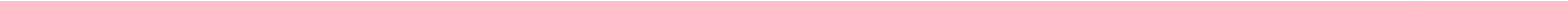




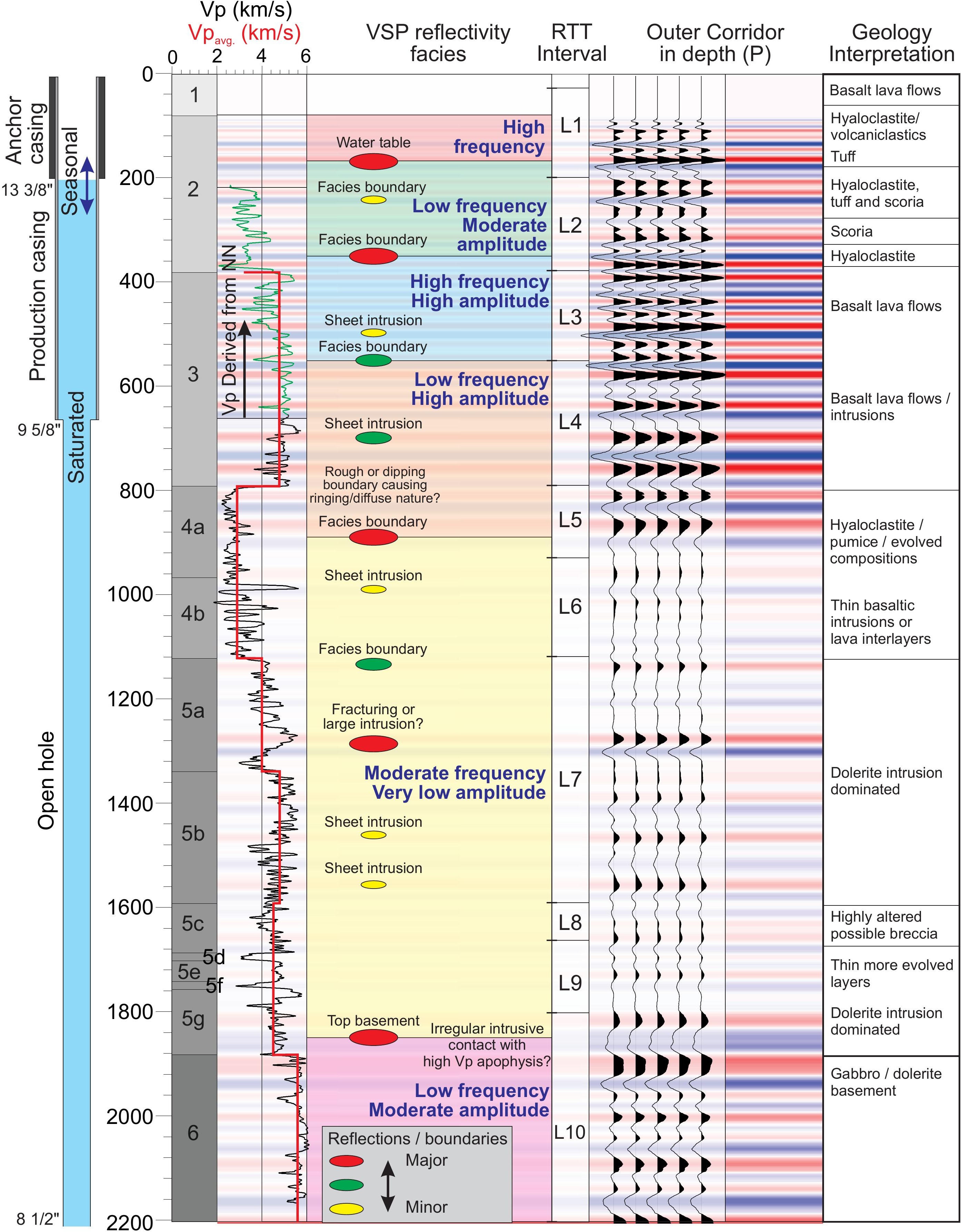

